\title{
Observations and regional modeling of aerosol optical properties, speciation and size distribution over Northern Africa and western Europe
}

\author{
Laurent Menut ${ }^{1}$, Guillaume Siour ${ }^{2}$, Sylvain Mailler ${ }^{1}$, Florian Couvidat ${ }^{3}$, and Bertrand Bessagnet ${ }^{3}$ \\ ${ }^{1}$ Laboratoire de Météorologie Dynamique, UMR CNRS 8539, École Polytechnique, École Normale Supérieure, Université \\ P.M.Curie, École Nationale des Ponts et Chaussées, Palaiseau, France \\ ${ }^{2}$ Laboratoire Inter-Universitaire des Systèmes Atmosphériques, UMR CNRS 7583, Université Paris Est Créteil et Université \\ Paris Diderot, Institut Pierre Simon Laplace, Créteil, France \\ ${ }^{3}$ Institut National de l'Environnement Industriel et des Risques, Verneuil en Halatte, 60550, Parc Technologique ALATA, \\ France
}

Correspondence to: Laurent Menut (menut@1md.polytechnique.fr)

Received: 30 March 2016 - Published in Atmos. Chem. Phys. Discuss.: 27 May 2016

Revised: 14 September 2016 - Accepted: 6 October 2016 - Published: 20 October 2016

\begin{abstract}
The aerosol speciation and size distribution is modeled during the summer 2013 and over a large area encompassing Africa, Mediterranean and western Europe. The modeled aerosol is compared to available measurements such as the AERONET aerosol optical depth (AOD) and aerosol size distribution (ASD) and the EMEP network for surface concentrations of particulate matter $\mathrm{PM}_{2.5}, \mathrm{PM}_{10}$ and inorganic species (nitrate, sulfate and ammonium). The main goal of this study is to quantify the model ability to realistically model the speciation and size distribution of the aerosol. Results first showed that the long-range transport pathways are well reproduced and mainly constituted by mineral dust: spatial correlation is $\approx 0.9$ for AOD and Angström exponent, when temporal correlations show that the day-to-day variability is more difficult to reproduce. Over Europe, $\mathrm{PM}_{2.5}$ and $\mathrm{PM}_{10}$ have a mean temporal correlation of $\approx 0.4$ but the lowest spatial correlation $(\approx 0.25$ and 0.62 , respectively), showing that the fine particles are not well localized or transported. Being short-lived species, the uncertainties on meteorology and emissions induce these lowest scores. However, time series of $\mathrm{PM}_{2.5}$ with the speciation show a good agreement between model and measurements and are useful for discriminating the aerosol composition. Using a classification from the south (Africa) to the north (northern Europe), it is shown that mineral dust relative mass contribution decreases from 50 to $10 \%$ when ni-
\end{abstract}

trate increases from 0 to $20 \%$ and all other species, sulfate, sea salt, ammonium, elemental carbon, primary organic matter, are constant. The secondary organic aerosol contribution is between 10 and $20 \%$ with a maximum at the latitude of the Mediterranean Sea (Spanish stations). For inorganic species, it is shown that nitrate, sulfate and ammonium have a mean temporal correlation of $0.25,0.37$ and 0.17 , respectively. The spatial correlation is better $(0.25,0.5$ and 0.87$)$, showing that the mean values may be biased but the spatial localization of sulfate and ammonium is well reproduced. The size distribution is compared to the AERONET product and it is shown that the model fairly reproduces the main values for the fine and coarse mode. In particular, for the fine mode, the model overestimates the aerosol mass in Africa and underestimates it in Europe.

\section{Introduction}

For the World Health Organisation (WHO), air pollution is a major environmental risk to health and particularly particulate matter (PM). The most health-damaging particles are those with a diameter of 10 microns or less $\left(\mathrm{PM}_{10}\right)$ which can penetrate and lodge deep inside the lungs. PM is responsible for a loss of life expectancy particularly when we consider long-term exposure to $\mathrm{PM}_{2.5}$ (Martinelli et al., 2013). 
Particles also play a role on the evolution of climate via direct and indirect effects (Stocker et al., 2013). In Europe, PM is still a major problem for regional air quality (AQ) (Guerreiro et al., 2013), and the member states have to take measures to reduce the exposure to comply with EU standards driven by international guidelines and regulations. A fraction of PM exceedances number is due to long-range transport of desert dust issued from the Saharan region, (Rea et al., 2015). In the AQ directive 2008/50/EC (European Union, 2008), chemistry-transport models (CTMs) are often cited as a technique to be used to assess AQ. The added value of using models for AQ management is summarized in Rouil and Bessagnet (2014) with, for instance, the possibility to subtract days of PM exceedances due to a Saharan dust outbreak. These models are also used for a better understanding of the atmospheric composition and the radiative impact of aerosol over Europe and Africa (Helmert et al., 2007; di Sarra et al., 2008; Vogel et al., 2009; Berg et al., 2015).

Even if the models are useful integrated tools, the measurements are the mandatory step to really understand the processes involved in the aerosol life cycle and thus its evolution in terms of composition and size distribution. During the last 15 years, many field experiments and long-term measurements in specific supersites were conducted. In Europe, Querol et al. (2004) analyzed several ground $\mathrm{PM}_{2.5}$ and $\mathrm{PM}_{10}$ measurements to estimate the chemical composition of the aerosol. This aerosol speciation was conducted to identify the relative contributions of organic and elementary carbon (OC and EC), mineral dust, marine and secondary inorganic aerosol. Depending on the measurements period and the location of the instruments, they showed the very high variability of the aerosol speciation in Europe. Also over Europe, Putaud et al. (2004) analyzed a large ensemble of surface measurements to estimate the chemical characteristics of aerosol depending on the measurements location (from urban to background sites). In the French Alps, Aymoz et al. (2004) studied the inorganic components of the aerosol during a Saharan dust long-range transport event. In Spain, Escudero et al. (2007) statistically analyzed surface PM$_{10}$ measurements to extract the relative part of mineral dust coming from Africa. Viana et al. (2008) reviewed several methodologies of chemical speciation determination for the source apportionment. In the eastern Mediterranean Basin for summer 2012, Kostenidou et al. (2015) analyzed the aerosol concentrations and their chemical compositions over the eastern Mediterranean. The fine aerosol $\left(\mathrm{PM}_{1}\right)$ was found to be dominated by organic aerosol and sulfate. From all these studies, and as synthesized in Kulmala et al. (2011) (after the European EUCARII project), one major conclusion is the need to better understand the aerosols speciation and size distribution. This need is also the conclusion of Laj et al. (2009), who list all existing methods to have better observations about the aerosol's chemical composition.

In the field of aerosol modeling, many developments were recently done to simulate these complex observations. At the global scale, and knowing the importance of the aerosol load and composition on Earth's climate, models were significantly improved and were able to accurately describe the different steps in the aerosol formation using complex schemes for nucleation, condensation and coagulation (Schutgens and Stier, 2014). These global models are compared and their strength and weakness are quantified, as, for example, in Huneeus et al. (2011) for the mineral dust emissions, transport and deposition in the framework of the AEROCOM project. However, due to computational cost, the global models have to use a limited number of modes or bins to describe the aerosol distribution. In addition, the validation of simulations is often restricted to datasets well documented over the globe, i.e., surface PM concentrations (without speciation) and aerosol optical depth (AOD), but with a low spatial resolution. CTMs at regional scale simulate the same processes but usually with a more accurate description for the processes involved in the aerosol formation and evolution.

At the regional scale, AQ models tend to underestimate PM and the main discrepancies are often attributed to a lack of emissions or difficulties to reproduce stable meteorological conditions during PM episodes (Bessagnet et al., 2016; Solazzo et al., 2012). The chemistry of secondary organic species and deposition is also a source of uncertainties (Bergström et al., 2012; Fountoukis et al., 2014). More generally for aerosol, one part of this uncertainty is linked to the fact that the size distribution modeling is poorly addressed in the literature. This size distribution will directly impact the aerosol behavior via the chemistry (nucleation, coagulation), the dry deposition (the settling velocity) and the wet deposition (the scavenging).

To go further in the aerosol life cycle understanding, it is now necessary to develop more constrained frameworks for the model vs. observations comparisons. The goal is to be able to answer new questions such as, (i) What is the chemical composition of the aerosol during its complete life cycle including emissions, transport and deposition? (ii) Is it possible to accurately identify the relative contributions of anthropogenic and natural emissions in the aerosol budget? (iii) If the surface PM surface concentrations and AOD are well modeled, are we sure there are no compensation errors in the chemical composition and radiative properties of the aerosol?

To answer these questions, numerical simulations are performed for the 2 months of June and July 2013 and over a large domain encompassing Africa and Europe. This period corresponds to the ADRIMED project presented in Mallet et al. (2016). The simulations are performed using two models: (i) the WRF meteorological model calculates the meteorological variables and (ii) the CHIMERE CTM calculates the fields concentrations of gaseous and aerosols using the meteorological fields. WRF and CHIMERE are widely used for regional studies of atmospheric of gaseous and aerosol species. Over this domain and for this period, the two models were already used in Menut et al. (2015a), Menut et al. 


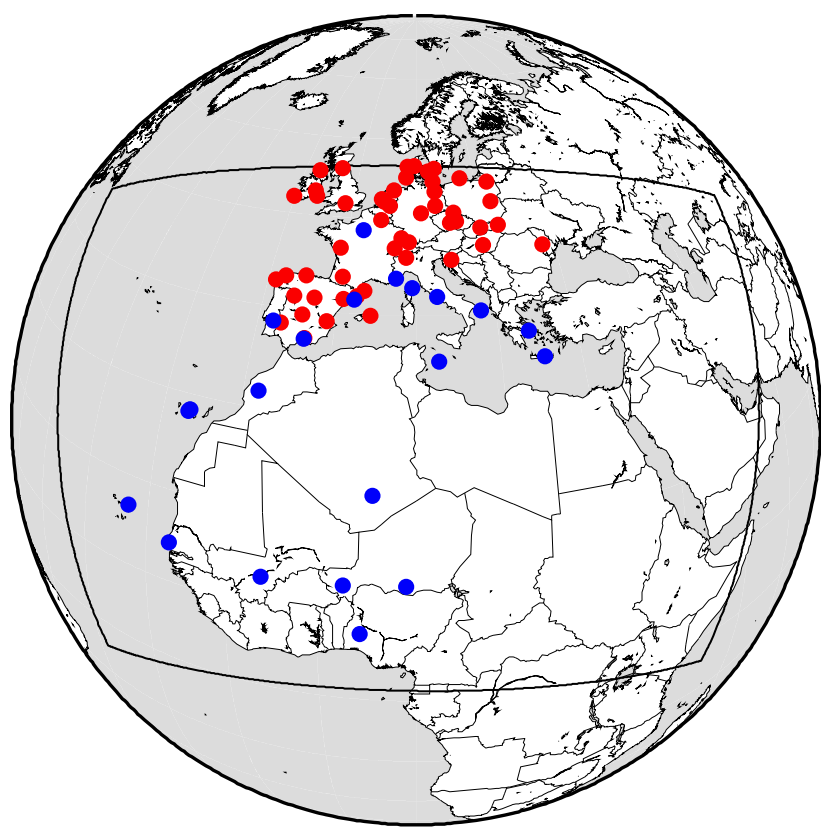

Figure 1. Locations of the measurements stations used in this study; in red are the EMEP stations and in blue are the AERONET stations. Names and coordinates of these stations are listed in Table 1 and Table 2.

(2015b) and Mailler et al. (2016a) and showed realistic results for the modeling of gaseous and aerosol species. In this study, the analysis is focused on the aerosol size distribution and its speciation in Africa and Europe.

The observations data and the models used are described in Sects. 2 and 3. The comparisons between observed and modeled concentrations are presented in Sect. 4 for the aerosol optical depth and the Ångström exponent (AE), Sect. 5 for the surface concentrations of $\mathrm{PM}_{2.5}$ and $\mathrm{PM}_{10}$, Sect. 6 for sulfate, nitrate and ammonium and Sect. 7 for the aerosol size distribution (ASD). Conclusions and perspectives are presented in Sect. 8.

\section{Observations}

Two types of observations are used in this study: (i) the surface concentrations of aerosols species with the EMEP network data and (ii) the column-integrated aerosol measurements with the AERONET (AErosol RObotic NETwork) network data, with AOD and size distribution. All stations locations are displayed in Fig. 1 with the EMEP stations in red and the AERONET stations in blue.

These stations were selected to cover the studied region: western Europe and the Mediterranean Sea, with additional stations in Africa representative of the mineral dust emissions before transport towards Europe.

\subsection{The EMEP network surface concentrations}

For the comparisons between observed and modeled concentrations, the background stations measurements performed during campaigns or in a routine way are used. All the stations are listed in Table 1 and displayed in Fig. 1. Depending on each station, several pollutants are measured: $\mathrm{O}_{3}$, $\mathrm{NO}_{2}, \mathrm{SO}_{2}, \mathrm{PM}_{2.5}$ and $\mathrm{PM}_{10}$. For some stations, the inorganic species sulfate, nitrate and ammonium are used.

These measurements are available on the EBAS database (http://ebas.nilu.no/) and are used here on a mean daily basis. Only the background stations are used due to the coarse horizontal resolution of the model. The altitude above sea level (a.s.l.) is presented for information. The representativity of the station depends on the sub-grid-scale variability of the model cell: the lower the variability, is the more representative the station is. Over mountains areas, it is rare and, generally, stations at high altitude a.s.l. cannot be considered as well representative of the first model level for concentrations. In our case, this is probably the case for the stations in the Alps. In this study, these stations were considered for the scores calculations but, in the case of poor comparisons scores, this problem of representativity could be a large part of the differences between model and observations. This is discussed in each case and in the following sections.

\subsection{The AERONET data}

The aerosol optical properties are compared between observations and model using the AERONET measurements (Holben et al., 2001). First, the comparison is done using the AOD measured by the AERONET photometers and for a wavelength of $\lambda=550 \mathrm{~nm}$. The level 2 data are used. Second, the comparison is performed using the ASD product level 1.5 , estimated after inversion of the photometers data as described in Dubovik and King (2000). For each AERONET station used in this study and listed in Table 2, the inversion algorithm provides volume particle size distribution for 15 bins, logarithmically distributed for radius between 0.05 and $15 \mu \mathrm{m}$.

\section{Modeling}

For the simulation performed in this study, two regional models are used: (i) the WRF meteorological model calculates the meteorological variables and (ii) the CHIMERE CTM calculates the fields concentrations of gaseous and aerosols using the meteorological fields. The horizontal domain is the same for the two models, with a constant horizontal resolution of $60 \mathrm{~km} \times 60 \mathrm{~km}$, as displayed in Fig. 1. This domain was selected to be sure to have all sources producing gas and aerosol concentrations around the Mediterranean Basin: European anthropogenic emissions, mineral dust and vegetation fires emissions. These species are mainly ozone and carbon monoxide for the gaseous species, mineral dust and organic 
Table 1. Names and locations of the EMEP stations used for model comparisons to aerosol surface concentrations. The stations are ordered from south to north. The altitude above sea level (a.s.l.) is indicated because the surface measurements are compared to the first model vertical level.

\begin{tabular}{lrrr|lrrr}
\hline Site & $\begin{array}{r}\text { Altitude } \\
(\mathrm{m} \text { a.s.l. })\end{array}$ & $\begin{array}{r}\text { Longitude } \\
\left({ }^{\circ}\right)\end{array}$ & $\begin{array}{r}\text { Latitude } \\
\left(^{\circ}\right)\end{array}$ & Site & $\begin{array}{r}\text { Altitude } \\
(\mathrm{m} \text { a.s.1. })\end{array}$ & $\begin{array}{r}\text { Longitude } \\
\left({ }^{\circ}\right)\end{array}$ & $\begin{array}{r}\text { Latitude } \\
\left({ }^{\circ}\right)\end{array}$ \\
\hline Viznar & 1265 & -3.53 & 37.23 & Revin & 390 & 4.63 & 49.90 \\
Barcarrola & 393 & -6.92 & 38.47 & Schmucke & 937 & 10.76 & 50.65 \\
Zarra & 885 & -1.10 & 39.08 & Sniezka & 1603 & 15.73 & 50.73 \\
SanPablo & 917 & -4.34 & 39.54 & Vredepeel & 28 & 5.85 & 51.54 \\
Campisábalos & 1360 & -3.14 & 41.28 & Harwell & 137 & -1.31 & 51.57 \\
Penausende & 985 & -5.86 & 41.28 & Jarczew & 180 & 21.98 & 51.81 \\
Els Torms & 470 & 0.71 & 41.40 & Valentia & 11 & -10.24 & 51.93 \\
Cap de Creus & 23 & 3.31 & 42.31 & Cabauw & 0 & 4.916 & 51.99 \\
Noya & 683 & -8.92 & 42.72 & Carnsore & 9 & -6.36 & 52.18 \\
O Saviñao & 506 & -7.69 & 43.23 & De Zilk & 4 & 4.50 & 52.30 \\
Niembro & 134 & -4.85 & 43.44 & Oak Park & 59 & -6.92 & 52.86 \\
Peyrusse & 200 & 0.18 & 43.61 & Neuglobsow & 62 & 13.03 & 53.16 \\
Iskrba & 520 & 14.86 & 45.56 & Kollumerwaard & 1 & 6.27 & 53.33 \\
Leova & 166 & 28.28 & 46.48 & Diabla Góra & 157 & 22.06 & 54.15 \\
La Tardière & 133 & -0.75 & 46.65 & Zingst & 1 & 12.73 & 54.43 \\
Payerne & 489 & 6.94 & 46.81 & Leba & 2 & 17.53 & 54.75 \\
K-puszta & 125 & 19.58 & 46.96 & Westerland & 12 & 8.30 & 54.92 \\
Tanikon & 539 & 8.90 & 47.47 & Malin Head & 20 & -7.34 & 55.37 \\
Schauinsland & 1205 & 7.90 & 47.91 & Risoe & 3 & 12.08 & 55.69 \\
Chopok & 2008 & 19.58 & 48.93 & Auchencorth & 260 & -3.24 & 55.79 \\
Starina & 345 & 22.26 & 49.05 & Vavihill & 175 & 13.15 & 56.01 \\
Košetice & 534 & 15.08 & 49.58 & Ulborg & 10 & 8.43 & 56.28 \\
Svratouch & 737 & 16.05 & 49.73 & Tange & 13 & 9.60 & 56.35 \\
\hline & & & & & & \\
\hline
\end{tabular}

matter (due to vegetation fires) for the aerosol. The modeled period ranged from 1 June to 30 July 2013. The results are presented from 10 June to 30 July 2013 to account for a spinup period.

\subsection{The WRF meteorological model}

The meteorological variables are modeled with the nonhydrostatic WRF regional model in its version 3.6.1 (Skamarock et al., 2007). The global meteorological analyses from NCEP/GFS are hourly read by WRF using nudging techniques for the main atmospheric variables (pressure, temperature, humidity, wind). In order to preserve both largescale circulations and small-scale gradients and variability, the "spectral nudging" was selected. This nudging was evaluated in regional models, as presented in Von Storch et al. (2000). In this study, the spectral nudging was selected to be applied for the large-scale dynamics (wave numbers less than 3 in latitude and longitude, for wind, temperature and humidity and only above $850 \mathrm{hPa}$ corresponding to all wavelength greater than $2000 \mathrm{~km}$ ). This configuration allows the regional model to create its own structures within the boundary layer but makes sure it follows the large-scale meteorological fields.

The model is used with 28 vertical levels from the surface to $50 \mathrm{hPa}$. The Single Moment-5 class microphysics scheme is used, allowing for mixed phase processes and super cooled water (Hong et al., 2004). The radiation scheme is RRTMG scheme with the MCICA method of random cloud overlap (Mlawer et al., 1997). The surface layer scheme is based on Monin-Obukhov with Carlson-Boland viscous sublayer. The surface physics is calculated using the Noah Land Surface Model scheme with four soil temperature and moisture layers (Chen and Dudhia, 2001). The planetary boundary layer physics is processed using the Yonsei University scheme (Hong et al., 2006) and the cumulus parameterization uses the ensemble scheme of Grell and Dévényi (2002). The aerosol direct effect is taken into account using the Tegen et al. (1997) climatology.

\subsection{The CHIMERE CTM}

\subsubsection{Overview}

CHIMERE is a CTM allowing the simulation of concentrations fields of gaseous and aerosol species at a regional scale. It is an offline model, driven by pre-calculated meteorological fields: for this study, the hourly WRF meteorological fields and the version fully described in Menut et al. (2013a) is used. If the simulation is performed with the same horizontal domain, the 28 vertical levels of the WRF simulations 
Table 2. Names and locations of the AERONET stations used for model comparisons to AOD and ASD data. The stations are ordered from south to north. The altitude a.s.l. is not presented, the measurements being representative of the vertically integrated atmospheric column above ground level (a.g.l.). The three codes are designed to clusterize the results at the end of this study; the classification mainly depends on the latitude of the station to split the domain into three main parts: Afr (for latitude below $\approx 30^{\circ} \mathrm{N}$ ), Med (between latitude $\approx 30$ and $\approx 45^{\circ} \mathrm{N}$ ) and Eur (for latitude up to $\approx 45^{\circ} \mathrm{N}$ ).

\begin{tabular}{|c|c|c|c|c|}
\hline Site & $\begin{array}{r}\text { Longitude } \\
\circ\end{array}$ & $\begin{array}{r}\text { Latitude } \\
\circ\end{array}$ & Code & Country \\
\hline Ilorin & 4.34 & 8.32 & Afr & Nigeria \\
\hline Cinzana & -5.93 & 13.27 & Afr & Mali \\
\hline Banizoumbou & 2.66 & 13.54 & Afr & Niger \\
\hline Zinder Airport & 8.98 & 13.75 & Afr & Niger \\
\hline Dakar & -16.95 & 14.39 & Afr & Senegal \\
\hline Cabo Verde & -22.93 & 16.73 & Afr & Cabo Verde \\
\hline Tamanrasset & 5.53 & 22.79 & Afr & Algeria \\
\hline Saada & -8.15 & 31.61 & Afr & Algeria \\
\hline Izana & -16.49 & 28.31 & Med & Tenerife \\
\hline Santa Cruz de Tenerife & -16.24 & 28.47 & Med & Tenerife \\
\hline La Laguna & -16.32 & 28.48 & Med & Tenerife \\
\hline Forth Crete & 25.27 & 35.31 & Med & Greece \\
\hline Lampedusa & 12.63 & 35.51 & Med & Italy \\
\hline Granada & -3.60 & 37.16 & Med & Spain \\
\hline Athens & 23.77 & 37.98 & Med & Greece \\
\hline Evora & -7.91 & 38.56 & Med & Portugal \\
\hline Lecce University & 18.11 & 40.33 & Med & Italy \\
\hline Barcelona & 2.11 & 41.38 & Med & Spain \\
\hline Rome Tor Vergata & 12.64 & 41.84 & Med & Italy \\
\hline Bastia & 9.44 & 42.69 & Med & France \\
\hline Villefranche & 7.32 & 43.68 & Eur & France \\
\hline Palaiseau & 2.21 & 48.70 & Eur & France \\
\hline Karlsruhe & 8.428 & 49.093 & Eur & Deutschland \\
\hline Lille & 3.142 & 50.612 & Eur & France \\
\hline Brussels & 4.350 & 50.783 & Eur & Belgium \\
\hline Chilbolton & -1.437 & 51.144 & Eur & United Kingdom \\
\hline Leipzig & 12.435 & 51.352 & Eur & Deutschland \\
\hline Cabauw & 4.927 & 51.971 & Eur & Netherlands \\
\hline
\end{tabular}

are projected onto 20 levels from the surface up to $200 \mathrm{hPa}$ for CHIMERE.

The chemical evolution of gaseous species is calculated using the MELCHIOR2 scheme. The photolysis rates are explicitly calculated using the FastJX radiation module (version 7.0b) (Wild et al., 2000; Bian et al., 2002). The modeled AOD is calculated by FastJX for the $600 \mathrm{~nm}$ wavelength over the whole atmospheric column. A complete analysis of the improvement obtained in the model with this online calculation is fully described in Mailler et al. (2016a). The way to redistribute the aerosol bins for the FastJX model is extensively described in Mailler et al. (2016b). At the boundaries of the domain, climatologies from global model simulations are used. In this study, outputs from LMDz-INCA (Szopa et al., 2009) are used for all gaseous and aerosols species, except for mineral dust where the simulations from the GOCART model are used (Ginoux et al., 2001).

\subsubsection{The modeled aerosols}

The aerosols are modeled using the scheme developed by Bessagnet et al. (2004). This module takes into account sulfate, nitrate, ammonium, primary organic matter (POM) and EC, secondary organic aerosol (SOA), sea salt, dust and water. The aerosol size is represented using 10 bins, from $40 \mathrm{~nm}$ to $40 \mu \mathrm{m}$, in mean mass median diameter (MMMD). The aerosol life cycle is completely represented with nucleation of sulfuric acid, coagulation, absorption, wet and dry deposition and scavenging. The scavenging is represented by incloud and sub-cloud scavenging.

The aerosol model species and their characteristics are displayed in Table 3. It consists in 10 different types of aerosols, some being a compound of several aerosol species.

The inorganic part constitutes the major part of the particulate matter in the fine mode (for $D_{\mathrm{p}}<2.5 \mu \mathrm{m}$ ). To determine 
Table 3. Properties of the modeled aerosol species. The density $\rho_{\mathrm{p}}$ is expressed as value $\times 10^{3} \mathrm{~kg} \mathrm{~m}^{-3}$. "anth", "bio" and "mineral" refer to the origin of the emission, respectively anthropogenic, biogenic and mineral dust.

\begin{tabular}{lllr}
\hline $\begin{array}{l}\text { Model } \\
\text { species }\end{array}$ & Origin & Description & $\begin{array}{r}\text { Density } \\
\rho_{\mathrm{p}}\end{array}$ \\
\hline $\mathrm{PPM}$ & anth & primary particulate matter & 1.50 \\
DUST & mineral & mineral dust & 2.65 \\
$\mathrm{EC}$ & anth & elemental carbon & 1.50 \\
$\mathrm{POM}$ & anth & primary organic matter & 1.50 \\
$\mathrm{SALT}$ & bio & sea salt & 2.10 \\
$\mathrm{SOA}$ & bio/anth & sec. organic aerosols & 1.50 \\
$\mathrm{SO}$ & anth & equiv. sulfate & 1.84 \\
$\mathrm{NO}_{3}$ & anth & equiv. nitrate & 1.70 \\
$\mathrm{NH}_{4}$ & anth & equiv. ammonium & 1.70 \\
$\mathrm{WATER}$ & - & water & 1.00 \\
\hline
\end{tabular}

the gas-particle partitioning of these semivolatile species, the ISORROPIA model is used (Nenes et al., 1998).

In the model, some processes are certainly roughly or not well represented. For the analysis, it is necessary to consider these approximations. This is the case for the formation of the coarse nitrate aerosol. Coarse nitrate is the result of chemical reaction of nitric acid with mineral dust and sea salt. This process and its impact on the European $\mathrm{PM}_{10}$ surface concentrations were studied in a previous version of CHIMERE, (Hodzic et al., 2006). In this current version, this process is not yet implemented due to missing information on the calcium carbonate mass. Thus, the modeled nitrate could be underestimated compared to measurements. Moreover, the formation of SOA formation from semivolatile organic compound is not represented in this CHIMERE version, since the emission inventories are not mature enough to account for this kind of emissions.

\subsection{Emissions}

Emissions are the only source in the atmospheric composition system and, thus, represent a large part of the uncertainty in the modeled concentrations. This uncertainty is related not only to the emitted mass flux itself (for gases and aerosol) but also to the size distribution for the modeled aerosol. In this model version, all kinds of anthropogenic and natural sources are taken into account on an hourly basis: the anthropogenic emissions are estimated using hourly time profiles and are thus hourly provided. The biogenic and mineral dust emissions (calculated online in CHIMERE) are using meteorological data and are also hourly estimated.

\subsubsection{Emission fluxes calculations}

The anthropogenic emissions are estimated using the same methodology as the one described in Menut et al. (2012) but using the global emission database EDGAR-HTAP annual
Table 4. Aerosols emissions with the three modes describing their size distribution: fine, coarse and big. The mean mass median diameter (MMMD) $D_{\mathrm{p}}$ is expressed in $\mu \mathrm{m} ; \sigma$ is unitless. "Mo86" refers to the parameterization of Monahan (1986).

\begin{tabular}{lrrr}
\hline \multirow{2}{*}{ Model } & \multicolumn{3}{c}{$D_{\mathrm{p}}(\mu \mathrm{m})+(\sigma)$} \\
\cline { 2 - 4 } species & Fine & Coarse & Big \\
\hline (sulfate) & $0.2(1.6)$ & & \\
POM (primary organic matter) & $0.2(1.6)$ & $4.0(1.1)$ & \\
EC (elemental carbon) & $0.2(1.6)$ & $4.0(1.1)$ & \\
PPM (primary particulate matter) & $0.2(1.6)$ & $4.0(1.1)$ & \\
SALT (sea salt) & & Mo86 & \\
WATER (water) & & Mo86 & \\
DUST (mineral dust) & $1.5(1.7)$ & $6.7(1.6)$ & $14.2(1.5)$ \\
\hline
\end{tabular}

totals as input data. The EDGAR-HTAP project compiled a global emission dataset with annual inventories at the national or regional scale that are likely to be acceptable for policy makers in each region of the world. This compilation of different official inventories from EMEP, UNFCCC, EPA for USA, GAINS for China and REAS was first gap-filled with global emission data (Janssens-Maenhout et al., 2012). The version 2 of this emission inventory was available for the year 2010. The available emitted species are listed in Table 4. PPM corresponds to the non-chemically reactive mass of particulate matter. The "fine" part of $\mathrm{H}_{2} \mathrm{SO}_{4}$ corresponds to $1 \%$ of the $\mathrm{SO}_{x}$ anthropogenic emissions and thus to primary sulfuric acid. These emissions were already used in this region and for this period in Menut et al. (2015a).

The biogenic emissions are calculated using the MEGAN emissions scheme (Guenther et al., 2006), which provides emission fluxes of nitrogen monoxide, isoprene and monoterpenes. The mineral dust emissions are calculated using new soil and surface databases described in Menut et al. (2013b) and with a spatial extension of potentially emitting areas in Europe. The dust production model used is the one of Alfaro and Gomes (2001). The sea salt emissions are calculated following the Monahan (1986) parameterization. Note that this scheme has its own size distribution. The "coarse" part of $\mathrm{H}_{2} \mathrm{SO}_{4}$ corresponds to the sulfate fraction of sea salt.

\subsubsection{Emission distributions in aerosols bins}

The way to distribute the primary emissions into the model bins will have a large impact on the finally modeled aerosols. For all aerosols, the primary emissions are provided with three main modes: fine, coarse and big. For each of these modes, a mean mass median diameter $D_{\mathrm{p}}$ is defined, with its associated $\sigma$. Depending on the emission type (anthropogenic, dust, sea salt, etc.), these parameters are different and are displayed in Table 4.

For the anthropogenic emissions, the species POM, EC and PPM are emitted only in the fine and coarse mode, with MMMD of 0.2 and $4 \mu \mathrm{m}$, respectively. $\mathrm{SO}_{4}$ is emitted in the fine mode only. Then, log-normal distributions are applied 


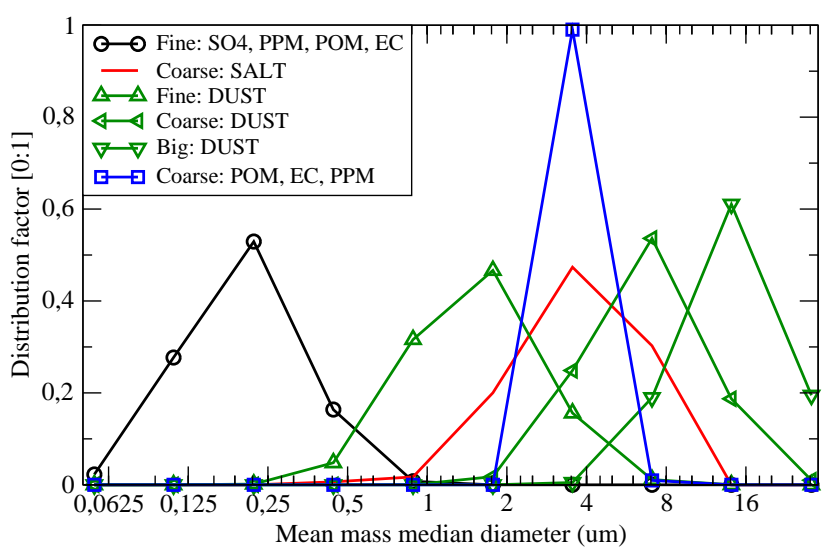

Figure 2. Distribution factors used to project the three aerosols emitted modes on the CHIMERE bins size distribution.

for these two modes to project the emissions into the model bins, as presented in Fig. 2. For the sea salt emissions, the distribution is directly the one proposed by Monahan (1986).

\section{Optical properties}

In this paper, the first observations vs. model comparison is done for AOD and AE. Correlations are calculated on a daily basis between the AERONET product and the values calculated in CHIMERE using the FastJX module as described in Mailler et al. (2016a).

\subsection{Aerosol optical depth}

The AOD calculated with CHIMERE does not correspond exactly to the available AERONET data. For the comparison between model and observations, the modeled AOD is interpolated on the AERONET wavelengths. For the region and studied period, the most complete AERONET dataset was found for AOD at $\lambda=675 \mathrm{~nm}$. The CHIMERE AOD useful for the interpolation are for $\lambda=600$ and $999 \mathrm{~nm}$. First, the $\mathrm{AE}$ is estimated as

$A\left(\lambda_{1}, \lambda_{2}\right)=\frac{-\log \left(\frac{\operatorname{AOD}\left(\lambda_{1}\right)}{\operatorname{AOD}\left(\lambda_{2}\right)}\right)}{\log \frac{\lambda_{1}}{\lambda_{2}}}$,

where $\lambda_{1}$ and $\lambda_{2}$ are two wavelengths and $\operatorname{AOD}\left(\lambda_{1}\right)$ and $\operatorname{AOD}\left(\lambda_{2}\right)$ the AOD corresponding to these two wavelengths. In case of this study, $\lambda_{1}=600 \mathrm{~nm}$ and $\lambda_{2}=999 \mathrm{~nm}$ with CHIMERE. Then, the interpolated AOD is obtained as

$\operatorname{AOD}\left(\lambda_{3}\right)=\operatorname{AOD}\left(\lambda_{2}\right) \exp \left(-A\left(\lambda_{1}, \lambda_{2}\right) \times \log \left(\lambda_{3} / \lambda_{2}\right)\right)$,

with $\lambda_{3}=675 \mathrm{~nm}$ for the comparison between CHIMERE and AERONET.

For the period from 10 June to 30 July 2013, and for all stations listed in Table 2, number of available data, correlations, root mean square error (RMSE) and bias are presented in Table 5 for AOD. Generally, the bias is slightly positive for locations close to mineral dust emissions (Banizoumbou, Cabo Verde, Dakar and Tamanrasset) and negative for locations far from these sources. This bias ranges from -0.14 (Brussels) to 0.28 (Dakar) and thus represents up to $100 \%$ of the AOD value. Compared to the AOD absolute value, the correlation is better: the temporal variability is better captured by the model than the mean average. The temporal variability is primarily explained by the meteorology (for dust emissions, transport and deposition of particles) and these correlations show that the model is able to reproduce the majority of huge aerosol plumes over the Mediterranean but failed for the north of Europe. The absolute value is more difficult to model because of its calculation methodology: the model uses a size distribution with a limited number of bins. Even if this approach is more realistic to describe the complex behavior of aerosols, it has some limitations: the number of bins and the values of the mean mass median diameter of the primary particles have a direct impact on all modeled processes (from the emissions to the deposition). The choice of the bins properties has also an impact on the AOD calculation itself: the distribution has to be projected on the extinction efficiency function, characterized by a narrow spread around the measured value. Thus, it is not surprising to have a large variability in AOD modeled values compared to measurements, but it does not mean that the aerosol life cycle is not well represented in the model.

Finally, the last row of Table 5 presents scores for all stations at the same time. $R_{\mathrm{S}}$ represents the correlation between the temporally averaged values of observed and modeled AOD. $R_{\mathrm{S}}$ shows that the low/high AOD values are very well estimated by the model, where and when they are observed by AERONET. The mean correlation is +0.3 , showing that some stations have low temporal correlations. The mean RMSE is 0.21 and the mean bias is 0.02 , showing that on average the positive bias (mainly in Africa) compensates the negative one (mainly in Europe).

\section{2 Ångström exponent}

In addition to the $\mathrm{AOD}$, the $\mathrm{AE}$ provides derived information on the size distribution of the aerosols in the vertically integrated atmospheric column. Depending on its value, one can have a first look of the dominant aerosol size in the atmosphere: mainly fine or mainly coarse. For low values, the atmospheric column is mainly composed of coarse particles (mineral dust and sea salt) when for large values the anthropogenic and biogenic contributions dominate.

After a complete screening of the available AERONET data, the most abundant information is for $A(440,870)$. In order to have the same information with CHIMERE, the modeled AODs are first estimated following the interpolation described in Eq. (1) and for wavelengths $\lambda=440$ and $870 \mathrm{~nm}$. Then, the corresponding AE is estimated using Eq. (2).

Results are presented in Table 6 . The mean averaged temporal correlation is better than for AOD, with $R=0.54$. This 
Table 5. Scores for the comparisons between observations (AERONET) and model (CHIMERE) for the aerosol optical depth (AOD). Results are presented with $N$ the number of daily mean available measurements for the period from 10 June to 30 July 2013, the temporal correlation $\left(R_{\mathrm{t}}\right)$, the root mean square error (RMSE) and the bias (model minus observations). The last line "average" represents the spatial correlation $R_{\mathrm{S}}$ between the mean observed and modeled values, and the mean averaged values of temporal correlation, RMSE and bias. Stations are sorted in increasing latitude, from south to north.

\begin{tabular}{|c|c|c|c|c|c|c|}
\hline \multirow[t]{2}{*}{ Site } & \multirow[t]{2}{*}{$N$} & \multicolumn{2}{|c|}{ AOD } & \multirow[t]{2}{*}{$R_{\mathrm{t}}$} & \multirow[t]{2}{*}{ RMSE } & \multirow[t]{2}{*}{ bias } \\
\hline & & Obs & Mod & & & \\
\hline Ilorin & 23 & 0.31 & 0.40 & 0.10 & 0.20 & 0.08 \\
\hline Cinzana & 52 & 0.50 & 0.51 & 0.58 & 0.25 & 0.01 \\
\hline Banizoumbou & 53 & 0.47 & 0.47 & 0.72 & 0.21 & 0.00 \\
\hline Zinder Airport & 55 & 0.45 & 0.65 & 0.69 & 0.38 & 0.20 \\
\hline Dakar & 44 & 0.54 & 0.81 & 0.57 & 0.42 & 0.28 \\
\hline Cabo Verde & 41 & 0.47 & 0.67 & 0.48 & 0.35 & 0.19 \\
\hline Tamanrasset & 60 & 0.36 & 0.42 & 0.01 & 0.32 & 0.06 \\
\hline Izana & 60 & 0.06 & 0.21 & 0.44 & 0.37 & 0.16 \\
\hline Santa Cruz de Tenerife & 59 & 0.13 & 0.21 & 0.48 & 0.33 & 0.08 \\
\hline La Laguna & 54 & 0.12 & 0.23 & 0.48 & 0.35 & 0.10 \\
\hline Saada & 58 & 0.22 & 0.40 & 0.32 & 0.57 & 0.18 \\
\hline Forth Crete & 40 & 0.10 & 0.09 & 0.54 & 0.06 & -0.01 \\
\hline Lampedusa & 43 & 0.15 & 0.25 & 0.63 & 0.26 & 0.10 \\
\hline Granada & 17 & 0.10 & 0.09 & 0.76 & 0.06 & -0.01 \\
\hline Athens & 47 & 0.12 & 0.10 & 0.47 & 0.08 & -0.02 \\
\hline Evora & 56 & 0.09 & 0.06 & 0.25 & 0.08 & -0.03 \\
\hline Lecce University & 46 & 0.12 & 0.10 & 0.17 & 0.10 & -0.03 \\
\hline Barcelona & 49 & 0.15 & 0.10 & 0.30 & 0.09 & -0.04 \\
\hline Rome Tor Vergata & 57 & 0.14 & 0.10 & 0.12 & 0.09 & -0.04 \\
\hline Bastia & 52 & 0.14 & 0.10 & 0.14 & 0.11 & -0.04 \\
\hline Villefranche & 37 & 0.13 & 0.09 & 0.09 & 0.13 & -0.04 \\
\hline Palaiseau & 44 & 0.16 & 0.07 & 0.04 & 0.13 & -0.09 \\
\hline Karlsruhe & 39 & 0.15 & 0.10 & 0.04 & 0.13 & -0.05 \\
\hline Lille & 35 & 0.19 & 0.06 & 0.03 & 0.16 & -0.12 \\
\hline Brussels & 30 & 0.19 & 0.06 & -0.14 & 0.18 & -0.14 \\
\hline Chilbolton & 30 & 0.16 & 0.05 & -0.09 & 0.15 & -0.11 \\
\hline Leipzig & 39 & 0.15 & 0.08 & 0.23 & 0.13 & -0.08 \\
\hline Cabauw & 35 & 0.16 & 0.05 & -0.06 & 0.13 & -0.10 \\
\hline Average & & $R_{\mathrm{S}}=$ & 0.90 & 0.30 & 0.21 & 0.02 \\
\hline
\end{tabular}

means that the size distribution (fine or coarse) is more accurately modeled than the AOD value itself. The bias (model minus observations) is large for all stations and negative. The bias increases with the latitude. This means that the model tends to diagnose too-low values of AEs and thus atmospheric columns with too much mass of particles in the coarse mode compared to the fine one. The mean spatial correlation $R_{\mathrm{S}}$ is good, with $R_{\mathrm{S}}=0.96$. This means that the longrange transport and the locations of the aerosol plumes are correctly estimated by the model.

\subsection{Optical properties maps}

In order to have another view of the model results, measured AOD and AE are overprinted on maps of these modeled variables in Fig. 3. This enables us to identify several cases, representative of the diversity of observed situations during this period of June and July 2013. Three days are selected: 18 June, 4 and 23 July, mainly because (i) 18 June corresponds to a strong peak discussed later in the article and (ii) the two other days are, more or less, with a step of 2 weeks, leading to a correct temporal coverage for the discussion. These days will be used as cases in the following parts of this study. The discussion is focused on western Africa, Europe and Mediterranean Sea, where the ADRIMED measurement campaign was performed (Mallet et al., 2016).

For 18 June 2013, a large dust plume, issued from Africa, reaches the western Europe, leading to large AOD values over France, Benelux and Germany. The plume is not spatially large but with important absolute values of AOD. In Africa, the model retrieves some high observed values, up to 0.5. In Europe, the model presents also an intense plume, but the measured values are less important, especially for 18 June 2013. The corresponding AE map first shows the dif- 
Table 6. Scores for the comparisons between observations (AERONET) and model (CHIMERE) for the Ångström exponent. Results are presented with $N$ the number of daily mean available measurements for the period from 10 June to 30 July 2013, the temporal correlation $\left(R_{\mathrm{t}}\right)$, the root mean square error (RMSE) and the bias (model minus observations). The last line "average" represents the spatial correlation $R_{\mathrm{S}}$ between the mean observed and modeled values, and the mean averaged values of temporal correlation, RMSE and bias. Stations are sorted in increasing latitude, from south to north.

\begin{tabular}{|c|c|c|c|c|c|c|}
\hline \multirow[t]{2}{*}{ Site } & \multirow[t]{2}{*}{$N$} & \multicolumn{2}{|c|}{ Ångström } & \multirow[t]{2}{*}{$R_{\mathrm{t}}$} & \multirow[t]{2}{*}{ RMSE } & \multirow[t]{2}{*}{ bias } \\
\hline & & Obs & Mod & & & \\
\hline Ilorin & 21 & 0.79 & 0.55 & 0.56 & 0.40 & -0.25 \\
\hline Cinzana & 44 & 0.27 & 0.29 & 0.51 & 0.19 & 0.02 \\
\hline Banizoumbou & 45 & 0.28 & 0.34 & 0.70 & 0.16 & 0.06 \\
\hline Zinder Airport & 46 & 0.32 & 0.26 & 0.71 & 0.16 & -0.07 \\
\hline Dakar & 44 & 0.26 & 0.09 & 0.67 & 0.22 & -0.17 \\
\hline Cabo Verde & 36 & 0.17 & 0.09 & 0.72 & 0.11 & -0.09 \\
\hline Tamanrasset & 51 & 0.16 & 0.08 & 0.57 & 0.11 & -0.08 \\
\hline Izana & 51 & 0.61 & 0.32 & 0.75 & 0.38 & -0.29 \\
\hline Santa Cruz de Tenerife & 50 & 0.67 & 0.32 & 0.51 & 0.48 & -0.35 \\
\hline La Laguna & 46 & 0.60 & 0.30 & 0.50 & 0.44 & -0.30 \\
\hline Saada & 49 & 0.37 & 0.26 & 0.63 & 0.22 & -0.10 \\
\hline Forth Crete & 34 & 1.31 & 0.86 & 0.65 & 0.52 & -0.45 \\
\hline Lampedusa & 43 & 1.17 & 0.64 & 0.80 & 0.61 & -0.53 \\
\hline Granada & 8 & 0.81 & 0.52 & 0.95 & 0.32 & -0.29 \\
\hline Athens & 38 & 1.61 & 0.97 & 0.75 & 0.68 & -0.64 \\
\hline Evora & 49 & 1.31 & 0.70 & 0.32 & 0.68 & -0.61 \\
\hline Lecce University & 46 & 1.59 & 1.11 & 0.72 & 0.54 & -0.48 \\
\hline Barcelona & 42 & 1.49 & 0.72 & 0.23 & 0.82 & -0.76 \\
\hline Rome Tor Vergata & 49 & 1.54 & 0.97 & 0.72 & 0.63 & -0.57 \\
\hline Bastia & 44 & 1.53 & 1.02 & 0.59 & 0.59 & -0.51 \\
\hline Villefranche & 33 & 1.56 & 0.93 & 0.69 & 0.67 & -0.62 \\
\hline Palaiseau & 37 & 1.41 & 0.88 & 0.40 & 0.60 & -0.53 \\
\hline Karlsruhe & 33 & 1.55 & 0.83 & 0.33 & 0.79 & -0.72 \\
\hline Lille & 28 & 1.36 & 0.90 & 0.51 & 0.52 & -0.46 \\
\hline Brussels & 25 & 1.47 & 0.97 & 0.04 & 0.57 & -0.51 \\
\hline Chilbolton & 22 & 1.19 & 0.67 & -0.05 & 0.63 & -0.52 \\
\hline Leipzig & 34 & 1.58 & 0.80 & 0.24 & 0.82 & -0.78 \\
\hline Cabauw & 26 & 1.26 & 0.82 & 0.37 & 0.51 & -0.44 \\
\hline Average & & $R_{\mathrm{S}}=$ & 0.96 & 0.54 & 0.48 & -0.39 \\
\hline
\end{tabular}

ferences between model and measurements. The low values of $\mathrm{AE}$ corresponding to the high values of AOD in the plume confirm the mineral dust origin of the aerosol. In addition, AE shows that the low AOD over the Mediterranean is not due to the absence of aerosols but to anthropogenic and biogenic aerosol with AE values up to 1 . At the south of the domain, high AE values are also modeled, showing the African forest fires in Central Africa.

For 4 July 2013, a very large area in Africa have high AOD values, up to 0.5 . Compared to the measurements, the model overestimates the AOD during the 3 days. One can also observe a thin mineral dust plume (with low AE) modeled over the Atlantic Ocean, coming from Africa and flowing until the north of France and the south of United Kingdom. On 5 July, and over the north of France, this aerosol plume appears on measurements a little further north than expected in the model simulations. Over western Europe, the AE values increase and values up to 1 cover the whole part of this region. Over Africa, AE values are low, showing the mineral dust dominance.

For 23 July 2013, two plumes are observed from Africa: one to the west and over the Atlantic sea and another one to the western Europe and over the Mediterranean Sea. The values are less important than for the two other studied days, but the plume has a larger spatial extent and covers the whole western Mediterranean Basin. The model is in good agreement with the measurements and the AOD values, between 0.1 and 0.5 , are well located by the model. As for the 4 July, the region composed by Germany and Benelux is mainly driven by high $\mathrm{AE}$ values, corresponding more to fine than coarse aerosol in the whole column: this result is both found for observations and model. 

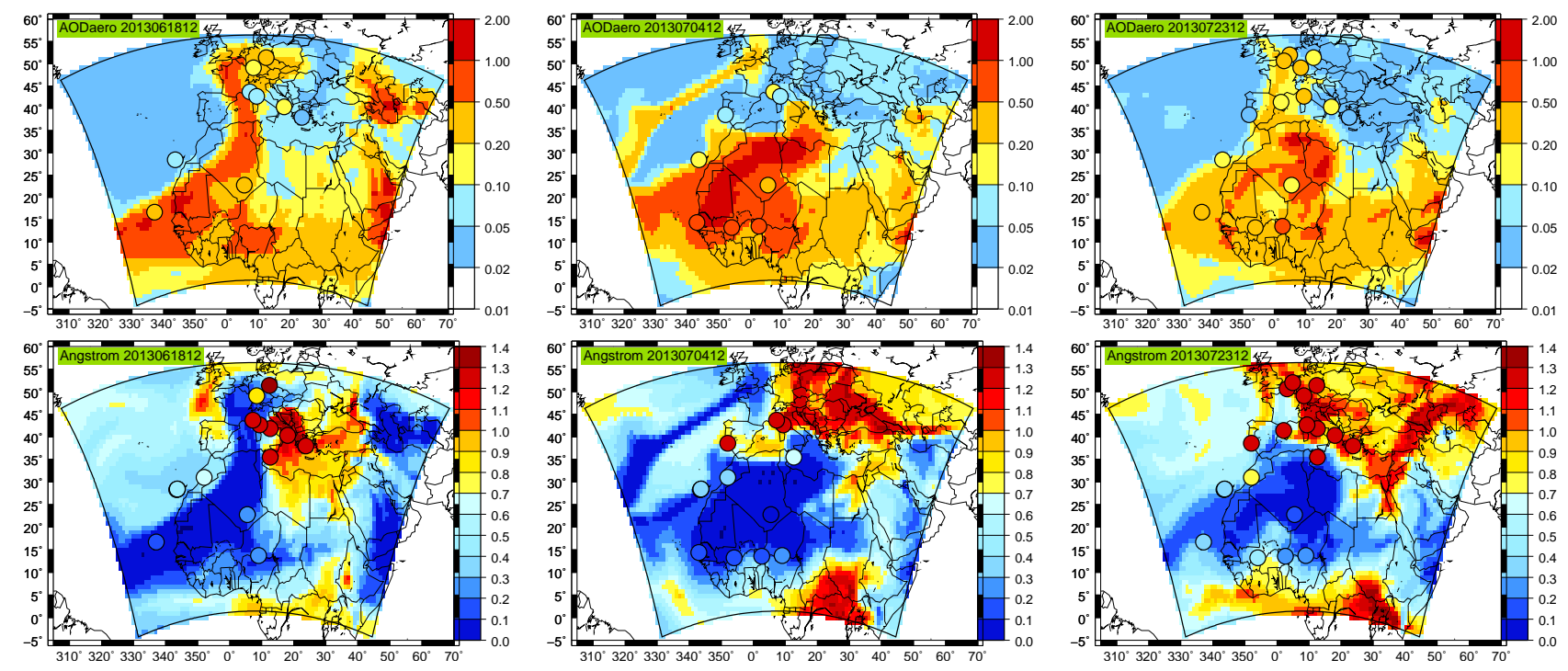

Figure 3. Maps for three different days - (left) 18 June, (middle) 4 July and (right) 23 July - and for the AOD (top) and the Ångström exponent (bottom). The AERONET measurements are superimposed to the modeled maps in colored circles.

\section{Surface $\mathbf{P M}_{2.5}$ and $\mathbf{P M}_{10}$ concentrations}

This section is dedicated to the comparison between modeled and observed PM. $\mathrm{PM}_{2.5}$ and $\mathrm{PM}_{10}$ families correspond to the sum of all aerosols described in Table 3, for mean mass median diameter lower than $D_{\mathrm{p}}=2.5$ and $10 \mu \mathrm{m}$, respectively.

\subsection{Scores for $\mathrm{PM}_{2.5}$ and $\mathrm{PM}_{10}$}

Comparisons between observed and modeled surface concentrations of $\mathrm{PM}_{2.5}$ and $\mathrm{PM}_{10}$ are presented in Table 7. Scores are calculated from 10 June to 30 July 2013, leading to a maximum of 51 daily values. The results are presented for the EMEP stations with $\mathrm{PM}_{2.5}$ and $\mathrm{PM}_{10}$ measurements at the same time.

The $\mathrm{PM}_{2.5}$ scores show an heterogeneous bias, depending on the location, ranging from -4.35 to $+3 \mu \mathrm{g} \mathrm{m}^{-3}$. Only five stations provide measurements for all days. However, except for Payerne (with only 12 days of measurements), all other stations provide more than 40 days on measurements, leading to representative statistics. In general, the correlations are satisfactory and around $\approx 0.5$ on average for all stations.

For $\mathrm{PM}_{10}$ measurements, only 9 stations out of 25 provide complete times series. The correlation is correct with a large spread in the values: the worst correlation, $R=-0.11$, is calculated in Leova while the best correlation, $R=0.6$, is found at Zarra. For the majority of stations, the model underestimates the concentrations.
More generally, these scores show that the processes leading to fine particles (emissions, chemistry) are better reproduced that the ones at the origin of large particles.

For these comparisons, the scores show that the model reproduces a large part of the observed temporal variability. For the aerosol mass, non-negligible biases appear with the simulation $(\approx 20 \%$ of the mass on average), negative or positive, depending of the location. The last row of Table 7 presents the correlation, $R_{\mathrm{S}}$, estimated using the mean averaged values of observed and modeled concentrations. This spatial correlation is better for $\mathrm{PM}_{10}\left(R_{\mathrm{S}}=0.62\right)$ than for $\mathrm{PM}_{2.5}\left(R_{\mathrm{S}}=0.25\right)$. The mean averaged values of correlation are close between $\mathrm{PM}_{2.5}$ and $\mathrm{PM}_{10}$ with 0.44 and 0.42 , respectively. Finally, the averaged bias is larger for $\mathrm{PM}_{10}$ (bias $=-1.10 \mu \mathrm{g} \mathrm{m}^{-3}$ ) than for $\mathrm{PM}_{2.5}$ (bias $=-0.49$ ), a logical result considering that the aerosol mass is much larger with $\mathrm{PM}_{10}$. These scores show that the order of magnitude of ground aerosol concentrations is correctly reproduced.

\subsection{Time series of $\mathbf{P M}_{2.5}$ speciation}

Time series of $\mathrm{PM}_{2.5}$ are presented to better explain the scores presented in the previous section. For the discussion, six sites are selected. The selection was made independently of the scores found but to be as representative of the largest region as possible. The precise location of these sites is displayed in Fig. 4 (red symbols). Harwell (United Kingdom) and Diabla Góra (Poland) are chosen for the north of Europe, Iskrba (Slovenia) and Schauinsland (Germany) for the center of Europe, and Campisábalos and Zarra (Spain) for the south of Europe.

The time series of $\mathrm{PM}_{2.5}$ speciation are displayed in Fig. 5. The symbols represent the $\mathrm{PM}_{2.5}$ EMEP observations. For all 
Table 7. Scores for the comparisons between observations (EMEP) and model (CHIMERE) for PM 2.5 and PM 10 . Results are presented with $N$ the number of daily mean available measurements for the period from 10 June to 30 July 2013 , the temporal correlation $\left(R_{\mathrm{t}}\right)$, the root mean square error (RMSE) and the bias (model minus observations). The last line "average" represents the spatial correlation $R_{\mathrm{S}}$ between the mean observed and modeled values, and the mean averaged values of temporal correlation, RMSE and bias. Stations are sorted in increasing latitude, from south to north.

\begin{tabular}{|c|c|c|c|c|c|c|c|c|c|c|c|c|}
\hline \multirow[t]{2}{*}{ Site } & \multicolumn{6}{|c|}{$\mathrm{PM}_{2.5}$} & \multicolumn{6}{|c|}{$\mathrm{PM}_{10}$} \\
\hline & $N$ & Obs & Mod & $R_{\mathrm{t}}$ & RMSE & bias & $N$ & Obs & Mod & $R_{\mathrm{t}}$ & RMSE & bias \\
\hline Viznar & 46 & 12.48 & 8.13 & 0.44 & 6.07 & -4.35 & 48 & 22.00 & 15.35 & 0.39 & 14.84 & -6.65 \\
\hline Barcarrola & 47 & 9.77 & 7.50 & 0.33 & 5.71 & -2.26 & 50 & 16.96 & 11.78 & 0.13 & 16.50 & -5.18 \\
\hline Zarra & 49 & 7.73 & 8.91 & 0.45 & 4.85 & 1.17 & 50 & 14.82 & 16.77 & 0.60 & 16.63 & 1.95 \\
\hline San Pablo & 51 & 8.00 & 6.40 & 0.48 & 3.53 & -1.60 & 51 & 15.20 & 10.12 & 0.24 & 10.51 & -5.08 \\
\hline Campisábalos & 43 & 9.56 & 7.49 & 0.58 & 4.01 & -2.07 & 45 & 10.98 & 10.78 & 0.38 & 8.35 & -0.20 \\
\hline Penausende & 49 & 6.65 & 6.22 & 0.56 & 2.91 & -0.43 & 50 & 11.06 & 7.82 & 0.38 & 5.80 & -3.24 \\
\hline Els Torms & 46 & 8.30 & 10.34 & 0.48 & 5.50 & 2.04 & 49 & 14.53 & 19.84 & 0.37 & 21.57 & 5.31 \\
\hline Cap de Creus & 46 & 9.33 & 12.23 & 0.16 & 7.73 & 2.90 & 46 & 18.35 & 31.07 & 0.26 & 42.79 & 12.72 \\
\hline O Saviñao & 43 & 10.14 & 9.03 & 0.68 & 3.93 & -1.11 & 43 & 13.26 & 13.14 & 0.53 & 4.42 & -0.12 \\
\hline Niembro & 48 & 8.23 & 10.49 & 0.58 & 5.04 & 2.26 & 48 & 17.02 & 14.55 & 0.58 & 6.53 & -2.47 \\
\hline Iskrba & 51 & 10.82 & 9.31 & 0.47 & 5.47 & -1.51 & 51 & 13.96 & 11.12 & 0.33 & 9.08 & -2.84 \\
\hline Payerne & 12 & 10.77 & 8.48 & 0.47 & 4.47 & -2.28 & 51 & 14.13 & 12.73 & 0.47 & 11.60 & -1.40 \\
\hline Schauinsland & 48 & 9.65 & 9.61 & 0.09 & 7.22 & -0.04 & 49 & 12.35 & 12.21 & 0.15 & 10.97 & -0.14 \\
\hline Košetice & 25 & 11.52 & 8.50 & 0.44 & 5.55 & -3.02 & 25 & 11.16 & 9.43 & 0.49 & 5.70 & -1.73 \\
\hline Schmucke & 51 & 8.11 & 7.95 & 0.41 & 5.02 & -0.15 & 51 & 11.95 & 9.36 & 0.44 & 7.15 & -2.59 \\
\hline Harwell & 51 & 7.81 & 7.96 & 0.63 & 3.84 & 0.15 & 51 & 13.24 & 9.84 & 0.56 & 6.21 & -3.40 \\
\hline Neuglobsow & 51 & 7.32 & 7.64 & 0.16 & 5.06 & 0.32 & 50 & 11.05 & 8.51 & 0.14 & 6.11 & -2.54 \\
\hline Diabla Góra & 50 & 8.22 & 6.24 & 0.52 & 3.52 & -1.98 & 51 & 11.43 & 7.25 & 0.57 & 5.46 & -4.18 \\
\hline Auchencorth & 41 & 5.22 & 7.89 & 0.48 & 3.86 & 2.67 & 2 & 7.00 & 7.89 & 1.00 & 0.99 & 0.89 \\
\hline Average & & $R_{\mathrm{S}}=$ & & 0.44 & 4.91 & -0.49 & & $R_{\mathrm{S}}=$ & & 0.42 & 11.12 & -1.10 \\
\hline
\end{tabular}

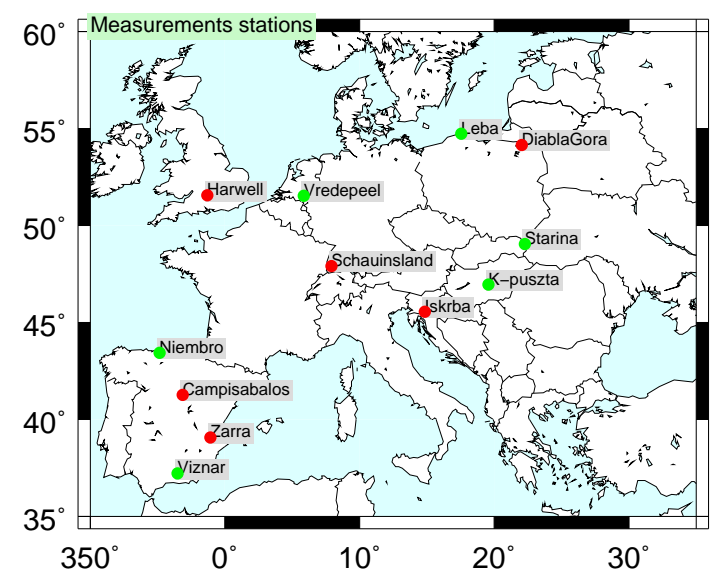

Figure 4. Location of the sites: (red symbols) surface time series of $\mathrm{PM}_{2.5}$ speciations are presented in Fig. 5; (green symbols) time series of $\mathrm{PM}_{10}$ for inorganic species are presented in Fig. 7.

sites, the cumulative concentrations until $D_{\mathrm{p}}<2.5 \mu \mathrm{m}$ of the model species show a good agreement in terms of mass and temporal variability. The important peak of $\mathrm{PM}_{2.5}$ observed around 18 June is well reproduced by the model for stations Harwell, Diabla Góra and Iskrba. This peak is overestimated in Schauinsland, mainly due to an overestimation of modeled mineral dust. This peak is mainly due to mineral dust except for at Iskrba, where this is mostly due to SOA and sulfate peak (mineral dust concentration remains low).

The event of 4 July shows less important concentrations, meaning that the AOD is related to long-range transport of aerosols in the troposphere and not to surface concentrations due to local emissions or chemistry. This peak is observed and modeled in Harwell and Campisábalos mainly. At the end of the modeled period, for the event of 23 July, the model shows the observed increase in surface concentrations in Harwell and Campisábalos but failed to estimate the right concentrations in Zarra (overestimation).

The view of the aerosol speciation shows that aerosol peaks, even if they appear at the same period, are not always due to the same chemical species increase.

In order to quantify the relative contribution of each species in the $\mathrm{PM}_{2.5}$ concentrations budget, percentages are presented for each EMEP measurements site and in Fig. 6. Values are presented for the stations where $\mathrm{PM}_{2.5}$ measurements were available. As previously discussed for the $\mathrm{PM}_{2.5}$ time series, the chemical composition is dominated by mineral dust and sulfate for all EMEP stations. If the mineral dust and sulfate relative contributions vary a lot (from 10 to $50 \%$ for mineral dust and from 20 to $40 \%$ for sulfate), the contribution of the other species is less variable: $\approx 15 \%$ for 

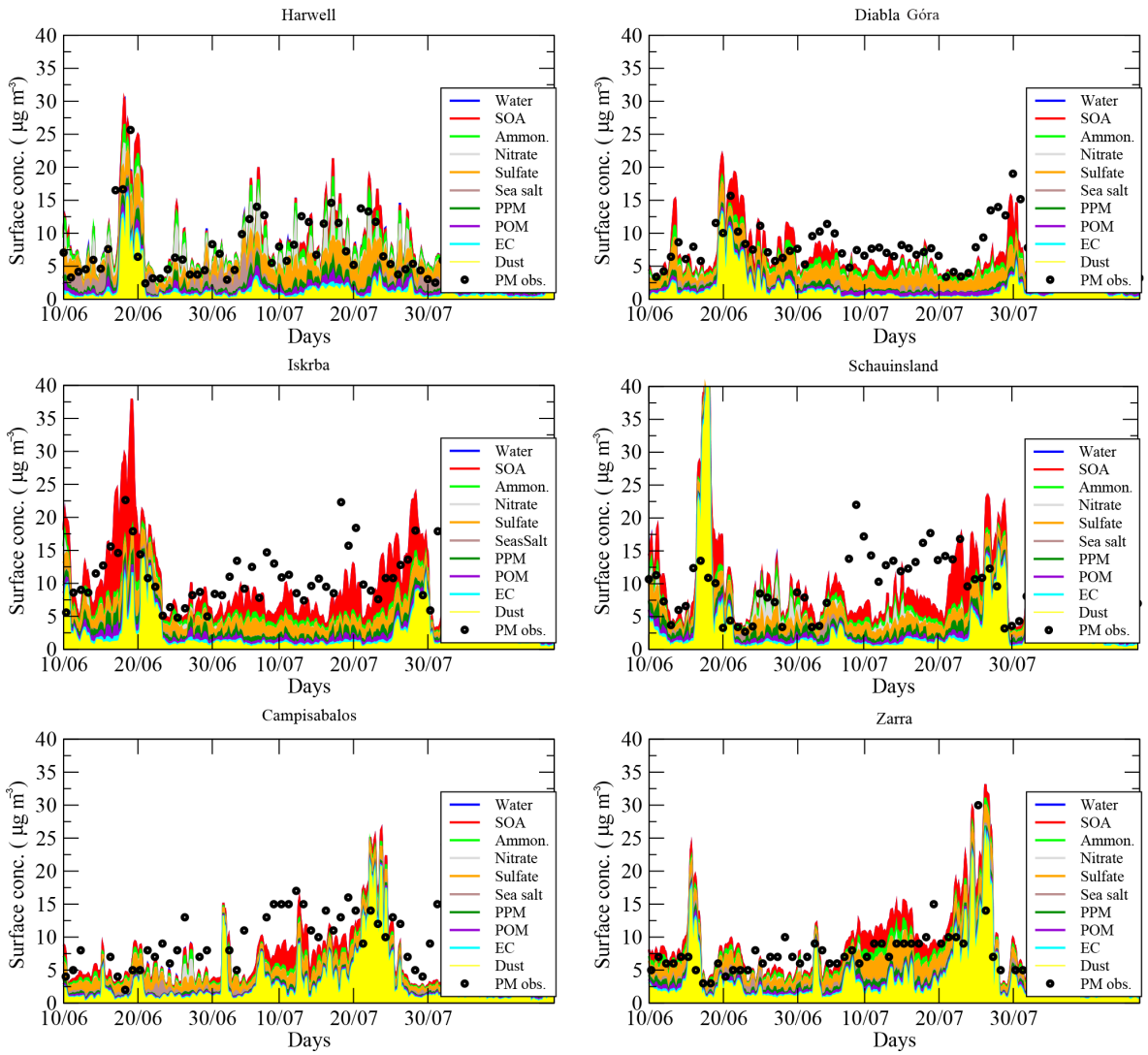

Figure 5. Time series of $\mathrm{PM}_{2.5}\left(\mu \mathrm{g} \mathrm{m}^{-3}\right)$ with the model aerosol speciation. The colors represent all constituents of the modeled aerosol (for $\left.D_{\mathrm{p}}<2.5 \mu \mathrm{m}\right)$ and the symbols represent the surface measurements of $\mathrm{PM}_{2.5}$.

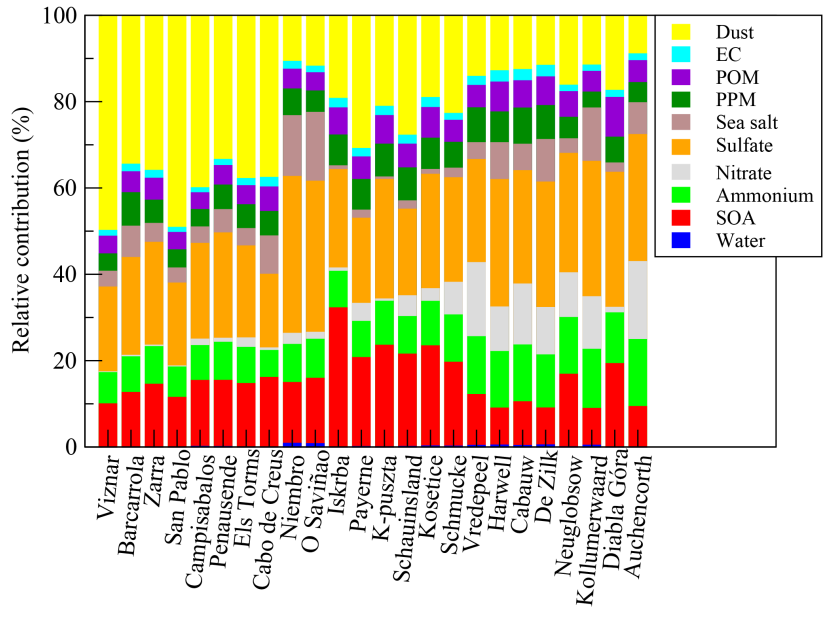

Figure 6. Relative contribution of each chemical species in the budget of the modeled $\mathrm{PM}_{2.5}$ surface concentrations for each EMEP station and on average over the period from 10 June to 30 July 2013.

$\mathrm{SOA}, \approx 10 \%$ for ammonium and less than $10 \%$ for the other components.

\section{Surface inorganic species concentrations}

The EMEP network provides surface measurements of nitrate, sulfate and ammonium for aerosol size until $10 \mu \mathrm{m}$ $\left(\mathrm{PM}_{10}\right)$. This is a good opportunity to evaluate the model capabilities to quantify these chemical species and to determine if the results of the previous sections are not due to error compensations.

From all EMEP stations listed in Table 1, the measurements of these three species are not systematic and regular in time. To quantify the model performance, statistical scores are calculated. The available measurements being different for the three species, the results are presented in different tables. The comparison is performed for ammonium, nitrate and sulfate, respectively, with 21,25 and 36 stations.

For $\mathrm{NH}_{4}$ comparisons, the results in Table 8 show a large variability for the correlation. The worst score $R=-0.18$ is at Leova, when the best score is at Viznar with $R=0.80$. The mean absolute values of concentrations are between 0.4 (Kpuszta) and 1.6 (Diabla Góra) and the RMSE exhibits values with the same order of magnitude, showing a non-negligible variability of the error. With values ranging between -0.87 (Diabla Góra) and 0.67 (De Zilk), the bias is important and also of the order of magnitude of the mean absolute value. 
Table 8. Scores for the comparisons between observations (EMEP) and model (CHIMERE) for the $\mathrm{NH}_{4}$ surface concentrations (in $\mu \mathrm{g} \mathrm{m}^{-3}$ ). Results are presented with $N$ the number of daily mean available measurements for the period from 10 June to 30 July 2013, the observed and modeled surface concentrations ("obs" and "mod"), the temporal correlation $\left(R_{\mathrm{t}}\right)$, the root mean square error (RMSE) and the absolute bias (model minus observations). The last line "average" represents the spatial correlation $R_{\mathrm{S}}$ between the mean observed and modeled values, and the mean averaged values of temporal correlation, RMSE and bias. Stations are sorted in increasing latitude, from south to north.

\begin{tabular}{lrrrrrr}
\hline \multirow{2}{*}{ Site } & $N$ & \multicolumn{2}{c}{$\mathrm{NH}_{4}$} & $R_{\mathrm{t}}$ & RMSE & bias \\
\cline { 3 - 4 } & & Obs & Mod & & & \\
\hline Viznar & 7 & 1.06 & 0.57 & 0.80 & 0.57 & -0.49 \\
San Pablo & 7 & 0.55 & 0.46 & 0.18 & 0.23 & -0.09 \\
Campisábalos & 7 & 0.48 & 0.79 & 0.39 & 0.43 & 0.31 \\
Els Torms & 7 & 0.84 & 0.90 & 0.74 & 0.20 & 0.06 \\
Niembro & 7 & 0.98 & 1.00 & 0.22 & 0.80 & 0.02 \\
Leova & 51 & 0.60 & 0.85 & -0.18 & 0.81 & 0.25 \\
K-puszta & 51 & 0.40 & 0.78 & -0.07 & 0.52 & 0.38 \\
Starina & 49 & 0.75 & 0.89 & 0.01 & 0.48 & 0.14 \\
Sniezka & 51 & 0.54 & 0.70 & 0.07 & 0.33 & 0.16 \\
Vredepeel & 26 & 0.88 & 1.40 & 0.10 & 1.25 & 0.52 \\
Jarczew & 46 & 1.13 & 0.83 & 0.27 & 0.52 & -0.31 \\
Carnsore & 51 & 0.54 & 0.72 & 0.12 & 0.72 & 0.18 \\
De Zilk & 25 & 0.64 & 1.31 & 0.76 & 0.98 & 0.67 \\
Oak Park & 51 & 0.67 & 0.83 & 0.78 & 0.53 & 0.16 \\
Neuglobsow & 51 & 0.38 & 0.96 & -0.10 & 0.73 & 0.58 \\
Diabla Góra & 49 & 1.60 & 0.73 & 0.06 & 1.39 & -0.87 \\
Leba & 51 & 1.03 & 1.01 & 0.42 & 0.38 & -0.02 \\
Malin Head & 44 & 0.47 & 0.70 & 0.59 & 0.48 & 0.22 \\
Risoe & 49 & 0.84 & 1.47 & -0.02 & 1.19 & 0.63 \\
Ulborg & 51 & 0.89 & 1.28 & 0.08 & 0.84 & 0.39 \\
Tange & 51 & 0.98 & 1.38 & 0.06 & 0.89 & 0.40 \\
\hline Average & & $R_{\mathrm{S}}=0.17$ & 0.25 & 0.68 & 0.16 \\
\hline & & & & & &
\end{tabular}

The row "average" in Table 9 shows that the spatial correlation of $\mathrm{NH}_{4}$ is very low with $R_{\mathrm{S}}=0.17$; this means that the model is not able to retrieve the $\mathrm{NH}_{4}$ plumes of high concentrations where and when they are observed. The mean averaged bias is +0.16 and represents $\approx 20 \%$ of the averaged concentrations, highlighting a non-negligible bias with the model for this species.

For $\mathrm{SO}_{4}$, in Table 9, results are better than for ammonium. The correlation $R$ ranges from -0.24 (K-puszta, but this is the only station with a negative correlation) to 0.78 (O Saviñao). The mean values of measured and modeled concentrations are larger than for ammonium and range from $\approx 1$ to $\approx 4 \mu \mathrm{g} \mathrm{m}{ }^{-3}$. The RMSE is satisfactory and never exceeds the half value of the mean concentration. The bias is scattered ranging from negative (until -0.87 at Cap de Creus) to positive values (until +1.23 at Chopok). The spatial correlation $R_{\mathrm{S}}=0.5$ is better than the one of $\mathrm{NH}_{4}$. The model is more able to retrieve the spatial variability of this pollutant than the temporal variability with the mean averaged corre-
Table 9. Scores for the comparisons between observations (EMEP) and model (CHIMERE) for the $\mathrm{SO}_{4}$. Results are presented with $\mathrm{N}$ the number of daily mean available measurements for the period from 10 June to 30 July 2013, the temporal correlation $\left(R_{\mathrm{t}}\right)$, the root mean square error (RMSE) and the bias (model minus observations). The last line "average" represents the spatial correlation $R_{\mathrm{S}}$ between the mean observed and modeled values and the mean averaged values of correlation, RMSE and bias. Stations are sorted in increasing latitude, from south to north.

\begin{tabular}{|c|c|c|c|c|c|c|}
\hline \multirow[t]{2}{*}{ Site } & \multirow[t]{2}{*}{$N$} & \multicolumn{2}{|c|}{$\mathrm{SO}_{4}$} & \multirow[t]{2}{*}{$R_{\mathrm{t}}$} & \multirow[t]{2}{*}{ RMSE } & \multirow[t]{2}{*}{ bias } \\
\hline & & Obs & Mod & & & \\
\hline Viznar & 49 & 2.15 & 1.48 & 0.65 & 0.89 & -0.66 \\
\hline Barcarrola & 50 & 1.84 & 1.45 & 0.73 & 0.84 & -0.40 \\
\hline Zarra & 50 & 2.11 & 1.87 & 0.53 & 0.91 & -0.24 \\
\hline San Pablo & 51 & 1.46 & 1.15 & 0.60 & 0.60 & -0.31 \\
\hline Campisábalos & 45 & 1.26 & 1.67 & 0.48 & 0.81 & 0.41 \\
\hline Penausende & 50 & 1.34 & 1.46 & 0.18 & 0.83 & 0.12 \\
\hline Els Torms & 49 & 2.19 & 1.95 & 0.45 & 0.95 & -0.25 \\
\hline Cap de Creus & 46 & 2.78 & 1.91 & 0.64 & 1.25 & -0.87 \\
\hline Noya & 50 & 1.86 & 2.31 & 0.56 & 1.47 & 0.45 \\
\hline Niembro & 48 & 3.27 & 3.53 & 0.74 & 2.05 & 0.26 \\
\hline O Saviñao & 43 & 2.29 & 3.02 & 0.78 & 1.85 & 0.73 \\
\hline Peyrusse & 15 & 2.55 & 1.95 & 0.47 & 1.31 & -0.60 \\
\hline Iskrba & 47 & 1.88 & 2.00 & 0.68 & 0.81 & 0.13 \\
\hline Leova & 51 & 2.20 & 2.38 & 0.02 & 2.25 & 0.18 \\
\hline La Tardière & 15 & 2.01 & 1.92 & 0.64 & 0.69 & -0.09 \\
\hline Payerne & 51 & 1.77 & 1.66 & 0.44 & 0.77 & -0.11 \\
\hline K-puszta & 51 & 2.89 & 2.07 & -0.24 & 1.74 & -0.82 \\
\hline Chopok & 50 & 1.14 & 2.36 & 0.17 & 1.57 & 1.23 \\
\hline Starina & 49 & 2.18 & 2.38 & 0.02 & 1.57 & 0.21 \\
\hline Košetice & 51 & 2.50 & 1.67 & 0.27 & 1.52 & -0.83 \\
\hline Revin & 15 & 1.99 & 2.25 & 0.72 & 0.86 & 0.26 \\
\hline Sniezka & 51 & 2.20 & 1.74 & 0.15 & 0.98 & -0.47 \\
\hline Vredepeel & 26 & 2.45 & 2.22 & -0.03 & 1.24 & -0.23 \\
\hline Jarczew & 43 & 2.85 & 2.24 & 0.34 & 1.69 & -0.61 \\
\hline Valentia & 51 & 1.27 & 1.80 & 0.59 & 1.09 & 0.53 \\
\hline Carnsore & 51 & 1.79 & 2.07 & 0.10 & 1.66 & 0.27 \\
\hline De Zilk & 25 & 2.49 & 2.87 & 0.48 & 1.25 & 0.38 \\
\hline Oak Park & 51 & 1.54 & 2.05 & 0.67 & 1.45 & 0.51 \\
\hline Neuglobsow & 51 & 1.64 & 2.05 & 0.06 & 1.01 & 0.41 \\
\hline Diabla Góra & 51 & 1.21 & 1.92 & 0.08 & 1.08 & 0.71 \\
\hline Leba & 49 & 2.49 & 2.61 & 0.12 & 1.42 & 0.12 \\
\hline Malin Head & 44 & 1.28 & 1.57 & 0.59 & 0.73 & 0.29 \\
\hline Risoe & 51 & 1.85 & 2.11 & 0.10 & 1.08 & 0.27 \\
\hline Vavihill & 44 & 1.10 & 2.08 & 0.33 & 1.16 & 0.98 \\
\hline Ulborg & 51 & 2.31 & 2.23 & 0.09 & 0.93 & -0.09 \\
\hline Tange & 50 & 2.00 & 2.08 & 0.11 & 0.84 & 0.08 \\
\hline Average & & $R_{\mathrm{S}}=$ & 0.50 & 0.37 & 1.20 & 0.05 \\
\hline
\end{tabular}

lation of 0.37 . The mean bias is very low $(+0.05)$ but the mean RMSE is high $(+1.20)$, showing that the model has the correct order of magnitude for this species but the model variability remains high.

Results for the nitrate are presented in Table 10. The comparison between observation and model is not fair: the model strongly underestimates the observed surface concentrations. In addition, the modeled concentrations temporal variability 
Table 10. Scores for the comparisons between observations (EMEP) and model (CHIMERE) for the nitrate. Results are presented with $N$ the number of daily mean available measurements for the period from 10 June to 30 July 2013, the temporal correlation $\left(R_{\mathrm{t}}\right)$, the root mean square error (RMSE) and the bias (model minus observations). The last line "average" represents the spatial correlation $R_{\mathrm{S}}$ between the mean observed and modeled values, and the mean averaged values of correlation, RMSE and bias. Stations are sorted in increasing latitude, from south to north.

\begin{tabular}{|c|c|c|c|c|c|c|}
\hline \multirow[t]{2}{*}{ Site } & \multirow[t]{2}{*}{$N$} & \multicolumn{2}{|c|}{$\mathrm{NO}_{3}$} & \multirow[t]{2}{*}{$R_{\mathrm{t}}$} & \multirow[t]{2}{*}{ RMSE } & \multirow[t]{2}{*}{ bias } \\
\hline & & Obs & Mod & & & \\
\hline Viznar & 49 & 1.02 & 0.05 & 0.17 & 1.08 & -0.97 \\
\hline Barcarrola & 50 & 0.83 & 0.08 & -0.16 & 0.84 & -0.75 \\
\hline Zarra & 50 & 1.39 & 0.07 & 0.11 & 1.41 & -1.32 \\
\hline San Pablo & 51 & 0.54 & 0.05 & -0.10 & 0.60 & -0.49 \\
\hline Campisábalos & 38 & 0.28 & 0.13 & 0.72 & 0.27 & -0.15 \\
\hline Penausende & 50 & 0.64 & 0.12 & -0.02 & 0.61 & -0.51 \\
\hline Els Torms & 49 & 0.47 & 0.25 & -0.07 & 0.54 & -0.21 \\
\hline Cap de Creus & 46 & 1.40 & 0.10 & 0.09 & 1.46 & -1.29 \\
\hline Noya & 40 & 0.90 & 0.16 & 0.14 & 0.91 & -0.74 \\
\hline Niembro & 46 & 0.97 & 0.24 & 0.41 & 0.86 & -0.73 \\
\hline O Saviñao & 41 & 0.74 & 0.18 & 0.28 & 0.62 & -0.56 \\
\hline Leova & 51 & 0.71 & 0.05 & 0.41 & 0.79 & -0.66 \\
\hline K-puszta & 51 & 0.69 & 0.09 & -0.04 & 0.69 & -0.60 \\
\hline Chopok & 50 & 0.60 & 0.17 & -0.13 & 0.61 & -0.43 \\
\hline Starina & 49 & 1.01 & 0.11 & 0.04 & 0.99 & -0.90 \\
\hline Sniezka & 51 & 1.54 & 0.32 & 0.17 & 1.38 & -1.22 \\
\hline Vredepeel & 26 & 4.53 & 2.19 & 0.01 & 4.40 & -2.34 \\
\hline Jarczew & 46 & 1.17 & 0.22 & 0.08 & 1.11 & -0.95 \\
\hline Carnsore & 50 & 1.60 & 0.40 & 0.21 & 2.12 & -1.21 \\
\hline De Zilk & 25 & 3.73 & 1.59 & 0.78 & 3.95 & -2.14 \\
\hline Oak Park & 51 & 1.30 & 0.55 & 0.71 & 1.14 & -0.75 \\
\hline Neuglobsow & 51 & 0.65 & 0.80 & 0.21 & 1.01 & 0.15 \\
\hline Diabla G’́ra & 50 & 1.28 & 0.24 & -0.01 & 1.35 & -1.04 \\
\hline Leba & 51 & 1.16 & 0.65 & -0.22 & 1.05 & -0.51 \\
\hline Malin Head & 44 & 0.84 & 0.71 & 0.45 & 0.99 & -0.13 \\
\hline Average & & $R_{\mathrm{S}}$ & .87 & 0.17 & 1.23 & -0.82 \\
\hline
\end{tabular}

is not satisfactorily, with low or negative correlation values. These bad results are mainly due to the missing formation of coarse nitrate. Viznar and Barcarrola illustrate this statement with a strong underestimate of nitrate concentrations, correlated with high simulated dust fraction in the $\mathrm{PM}_{10}$ concentrations.

In order to have more information about the temporal variability of these inorganic species concentrations, time series are presented for specific sites where the three species were measured simultaneously with a sufficient number of data. Results are presented in Fig. 7 for Leba, Niembro, Starina, Viznar, K-puszta and Vredepeel. These locations are reported in Fig. 4. Even if the performances of the model seem poor, these time series show that the order of magnitude of inorganic species is fairly reproduced (except for nitrate). It means that even if the sources and the chemistry remain uncertain, the inorganic equilibrium diagnosed using the ISORROPIA module works well to ensure realistic inorganic chemistry and partitioning, whatever the location and the period in summer 2013.

Another analysis of the results is presented in Fig. 8. The three rows correspond to the 3 days of 18 June, 4 and 23 July 2013. The three columns are for sulfate, nitrate and ammonium. For each map, the modeled surface concentrations are expressed in $\mu \mathrm{g} \mathrm{m}^{-3}$ over the whole simulation domain. Since the measurements are restricted to Europe with the EMEP measurements, a magnification is done to focus on Europe. For each time and each pollutant, the corresponding observed ground concentrations is superimposed as colored circles on the map.

For sulfate, and for the 3 selected days, the surface concentrations are higher than for nitrate and ammonium, as already discussed in the previous section both for observations and modeling. The most important modeled concentrations are found over the seas (Mediterranean Sea and English Channel). Over land in Europe, the concentrations remain low and the model reproduces well the observed concentrations. Some peaks corresponding to advected plumes are observed and also well modeled as in Benelux and Italy (18 June), north of Spain (7 and 23 July). For this species, the model is able to reproduce the largest spatial patterns with the correct order of magnitude of the concentrations.

For nitrate, the modeled concentrations are low and mainly concentrated in the English Channel. This effectively corresponds to the largest measured values as in the western United Kingdom (18 June) and Benelux (7 and 23 July). The addition of $\mathrm{NO}_{x}$ shipping and anthropogenic emissions (advected above the sea) is responsible for the formation of nitrate favored by mild, humid conditions and low deposition over the Channel. For all other parts of the modeled domain, the model estimates concentrations below $0.2 \mu \mathrm{g} \mathrm{m}^{-3}$ when the observations ranged between 0.1 and $1 \mu \mathrm{g} \mathrm{m}^{-3}$, highlighting a systematic underestimation of the model for background values over land.

For ammonium, the modeled background concentrations are higher than for nitrate and ranged from 0.2 to $1 \mu \mathrm{g} \mathrm{m}^{-3}$. This is in agreement with the observed values and when the highest concentrations are observed, the model simulates a plume close to these areas. Performances on ammonium follow the ones of sulfate, most of the ammonium reacts with sulfuric acid to form ammonium sulfate salts.

\section{Aerosol size distribution}

In the previous section, the speciation was studied only at the surface using EMEP measurements. An additional way is to use the AERONET inversions to have ASD to compare to model results. Two types of comparisons are presented in this section: (i) direct comparison of ASD between model and observations, where and when AERONET inversion products are available; (ii) a comparison of fine and coarse mode val- 

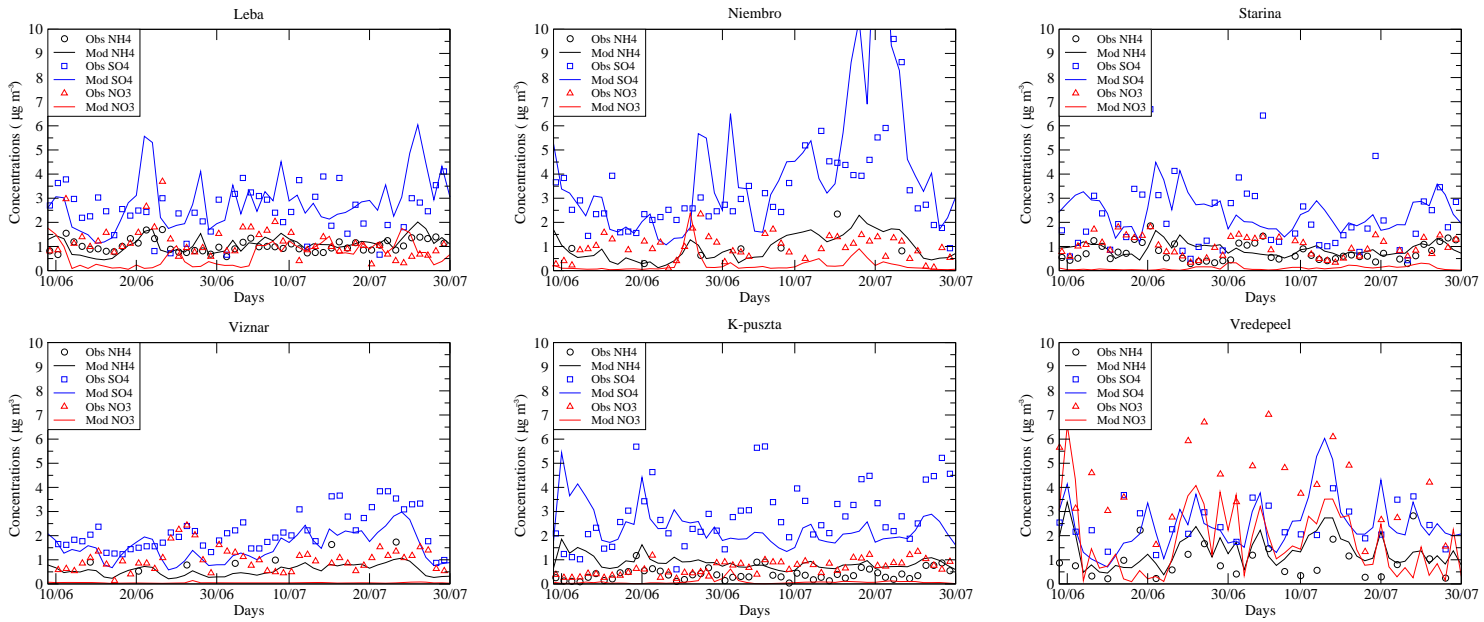

Figure 7. Time series of $\mathrm{PM}_{10}\left(\mu \mathrm{g} \mathrm{m}^{-3}\right)$ for the modeled and measured surface inorganic species.
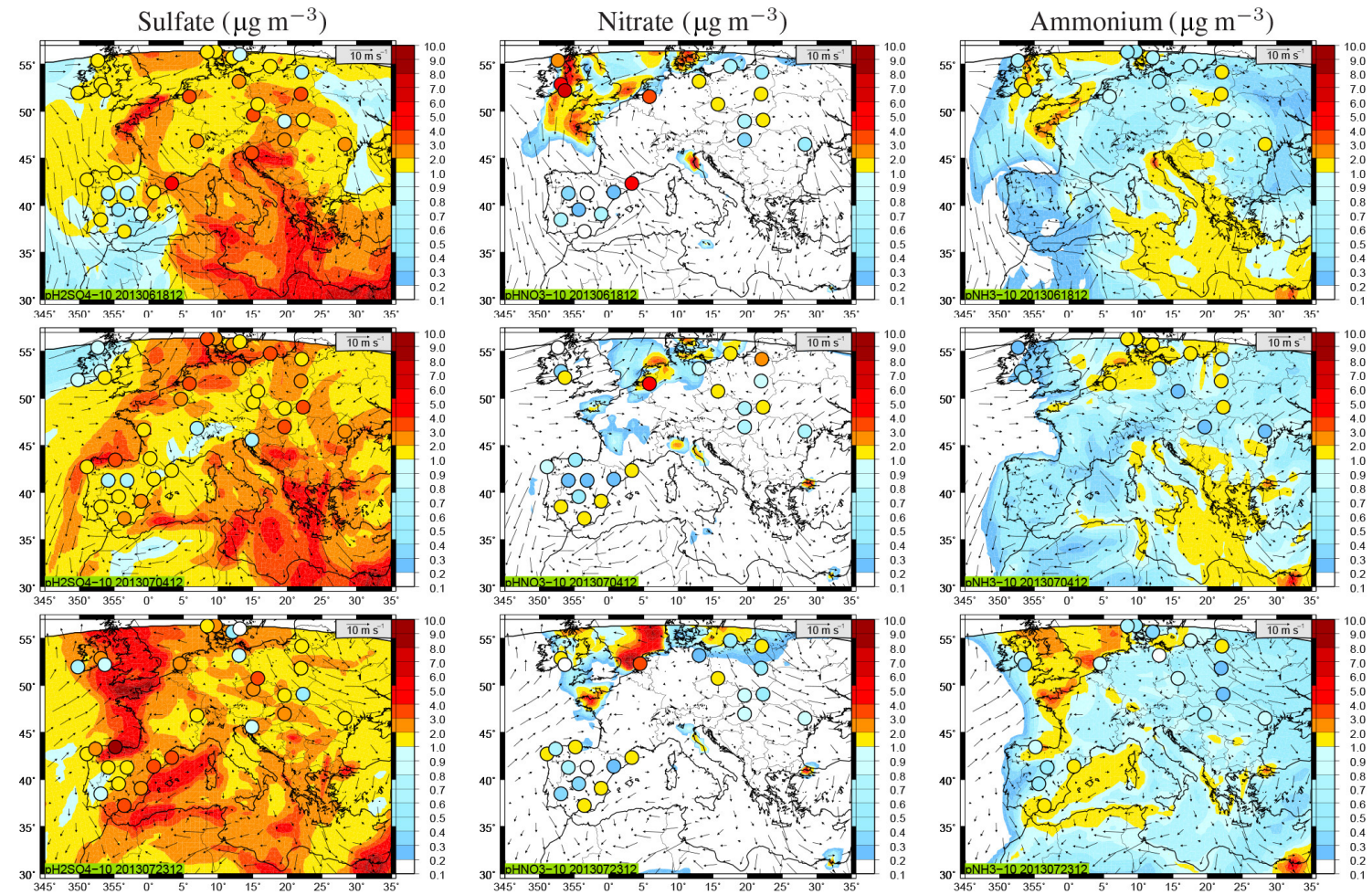

Figure 8. Maps of sulfate, nitrate and ammonium $\left(\mu \mathrm{g} \mathrm{m}^{-3}\right)$ for 18 June, 4 and 23 July 2013. A magnification is done over western Europe where EMEP surface measurements (superimposed to the model) are available. All concentrations values lower than $0.2 \mu \mathrm{g} \mathrm{m}^{-3}$ are considered to be nonsignificant and are not colored. The $10 \mathrm{~m}$ (a.g.1.) wind speed is superimposed as vectors.

ues to quantify the ability of the model to estimate the size distribution changes.

\subsection{ASD speciation}

As presented in Sect. 2, the AERONET inversion products provide ASD for 15 bins, following a logarithmic distribution, ranging from 0.05 to $15 \mu \mathrm{m}$. In order to conserve all model information, the calculation is done on the AERONET bins plus extra bins in the finest and coarsest sizes: five bins are added below $0.05 \mu \mathrm{m}$ with $r=0.005,0.01,0.02$, 0.03 and $0.04 \mu \mathrm{m}$ and three bins are added after $15 \mu \mathrm{m}$ with $r=20,30$ and $40 \mu \mathrm{m}$. The model bins are interpolated on the AERONET bins and the column aerosol volume size distri- 
bution is calculated for each bin $i$ as in Péré et al. (2010):

$$
\frac{\mathrm{d} V\left(r_{i}\right)}{\mathrm{d} \ln r_{i}}=\sum_{k=1}^{n \text { levels }} \sum_{a=1}^{n \text { aero }} \frac{m_{\mathrm{a}}\left(k, r_{i}\right) \times \Delta z(k)}{\rho_{\mathrm{a}} \times \ln \left(r_{i, \max } / r_{i, \min }\right)},
$$

where $r_{i}$ is the mean mass median radius and $r_{i, \min }$ and $r_{i, \max }$ the boundaries of the $i$ th bin. $m_{\mathrm{a}}\left(k, r_{i}\right)$ is the aerosol mass concentration (the mass of aerosol in cubic meter of air, in $\mu \mathrm{g} \mathrm{m}^{-3}$ ) for the $n$ aero modeled aerosols. $\rho_{\mathrm{a}}$ is the aerosol density (also in $\mu \mathrm{g} \mathrm{m}^{-3}$, the mass of the particle in its own volume). The aerosols densities are fixed for each model species and displayed in Table 3. $\Delta z(k)$ is the model layer thickness (for a total of $n$ levels, here 20 vertical levels).

In order to conserve all model information, the calculation is done on the AERONET bins plus extra bins in the finest and coarsest sizes: five bins are added below $0.05 \mu \mathrm{m}$ with $r=0.005,0.01,0.02,0.03$ and $0.04 \mu \mathrm{m}$ and three bins are added after $15 \mu \mathrm{m}$ with $r=20,30$ and $40 \mu \mathrm{m}$.

The model ASD calculation is done independently for each aerosol species in order to have the chemical speciation. All aerosol ASD are cumulated and are thus directly comparable to the AERONET ASD. Results are presented in Fig. 9 for the three selected periods and for several AERONET stations (chosen to be representative of several locations in the modeled domain).

For modeled and observed concentrations, two main modes are observed: a fine mode with $r \approx 0.1 \mu \mathrm{m}$ and a coarse mode with $r \approx 1$ to $5 \mu \mathrm{m}$. These modes differ a lot between days and locations. In these examples, there is no systematic bias between the model and the observations regarding the values of the modes radius. A more systematic comparison is presented in the next section. The speciation is presented for the model and cumulated over all species to have a direct comparison to the AERONET ASD.

For the fine mode, the main modeled species are SOA, sulfate and ammonium. The composition varies a lot from one site to another: in Athens (18 June) SOA and sulfate dominate, while in Evora (23 July) only SOA dominates with a lowest contribution of PPM. For all days and stations, the fine mode is underestimated by the model and exhibits a distribution larger than the AERONET fine mode.

For the coarse mode, the main modeled species is mineral dust. For sites close to this source, the ASD shows a correct order of magnitude (Banizoumbou for 18 June, Cabo Verde for 4 July). Far from the African dust sources, the mineral dust contribution may be under or overestimated by a factor of 2 (Evora for the 18 June, Barcelona for 23 July). The best comparisons are obtained when the measured coarse mode is centered on $r \approx 2 \mu \mathrm{m}$ as, for example, in Banizoumbou (18 June), Izana and Santa Cruz Tenerife (23 July).

\subsection{ASD fine and coarse modes}

In order to have a global view of the model capability to estimate the aerosol size distribution, a simple calculation of these distribution characteristics is done for all sites and hours where AERONET measurements are available. An example is displayed in Fig. 10. Most of the AERONET ASD exhibit a two-mode distributions, with a "fine" and a "coarse" mode. This is due to the AERONET inversion methodology itself, searching for a local minimum of $\mathrm{d} V / \mathrm{d} \log (r)$ between 0.439 and $0.992 \mu \mathrm{m}$ for the aerosol radius. The same analysis is done for the modeled ASD. From these two local minimum values, the local maxima are quantified for the "fine" and "coarse" mode.

The values of radius are compared between the model and the observations in Fig. 11. Since the radius in the size distribution is estimated using a logarithmic progression, the results are also presented using a logarithmic scale. For the observed and modeled distributions, the bins are discretized: this explains the few number of points on the scatter plot, even if numerous data were analyzed.

The results are classified with three categories: "Africa", "Europe" and "Mediterranean". This classification is related to the stations location (the latitude as explained in Table 2) and enables us to see if any systematic trends appear. The results show a large variability of the differences between model and observations, both for the "fine" and "coarse" modes.

For the two modes, this scatter plot first shows that the variability is larger in the observations than in the model: for one observed specific radius the model found three to four different radius, while for one modeled radii, five to six different radii are found in the observations.

For the "fine" mode and for the stations denoted "Africa", the model overestimates the radius by a factor of 2: for the largest occurrences of radius values, when the observations are around $r \approx 0.1 \mu \mathrm{m}$, the corresponding model value is $r \approx$ $0.2-0.3 \mu \mathrm{m}$. For the "Mediterranean" stations, there is a large spread between model and observations but no systematic bias: the fine mode is correctly modeled with $r \approx 0.1 \mu \mathrm{m}$. For "Europe" stations, the trend is different and a systematic bias appears: in this case, the model underestimates the observed radius by a factor of 2 .

For the "coarse" mode, the same behavior is observed as for the "fine" mode. A large spread is observed between observations and model, but with well-marked trends, depending on the stations location. When the radius is overestimated in Africa, it is well retrieved for Mediterranean stations and underestimated in Europe.

Another way to quantify the differences between the observed and modeled modes is to sum the $\mathrm{d} V / \mathrm{d} \log (r)$ values for the observations and the model and independently for the "fine" and "coarse" modes. The modes are split considering a constant radius of $r=0.5 \mu \mathrm{m}$. This choice of a constant value is done to avoid the bias observed in the radius retrieval presented in Fig. 11.

Results for this comparison are presented in Fig. 12. For the fine mode, the cumulated mass of aerosol shows a clear tendency between the three regions: the model overesti- 

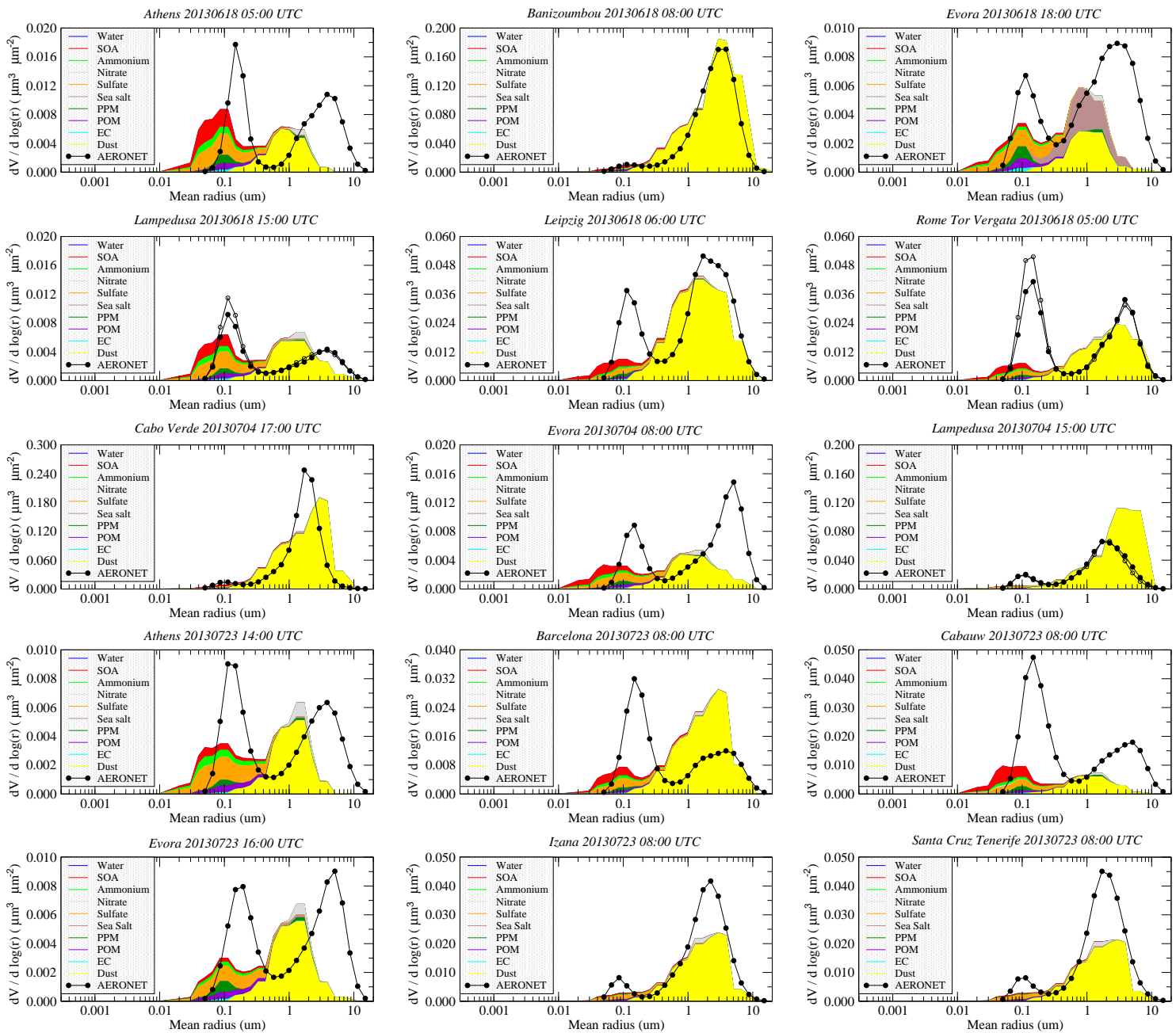

Figure 9. Comparisons between observed (AERONET) and modeled (CHIMERE) aerosol size distribution for 18 June, 4 and 23 July 2013. For the model results, the aerosol speciation is displayed with different colors for each species.

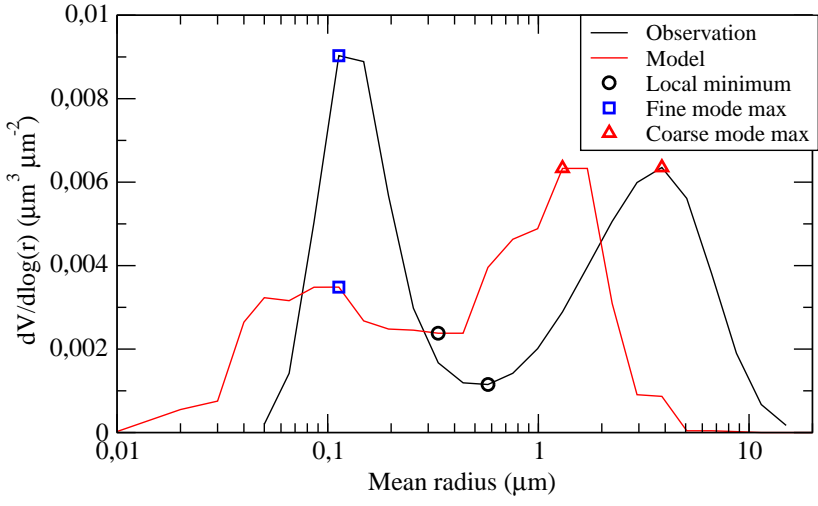

Figure 10. Method for the local minima and maxima values estimation. This example corresponds to the ASD for Athens, 23 July 2013, 14:00 UTC. mates the concentrations in Africa, slightly underestimates the aerosol load over Mediterranean Sea and clearly underestimates the values in Europe.

The results are less marked for the coarse mode but follow the same tendency. In addition, the spread of the cumulated mass is larger than for the fine mode. Over Africa, the model overestimates the aerosol mass, and this concerns high mass values. However, the model tends to underestimate the mass over the Mediterranean Sea and this corresponds to low mass values. Over Europe, the model underestimates the low mass values, but overestimates the highest mass values. Clearly, the case of the Mediterranean stations corresponds to a mixture of anthropogenic and biogenic aerosol (mainly emitted in Europe) and mineral dust aerosol (mainly emitted in Africa). 


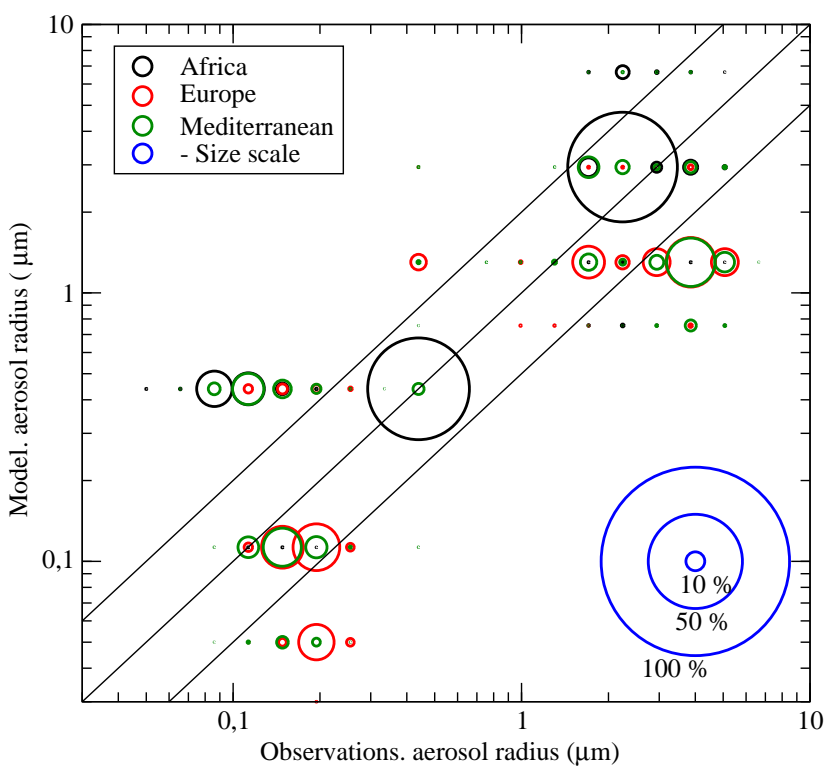

Figure 11. Scatter plot of the radius found in observations and model for the fine and coarse modes. The width of each symbol represents the occurrence for each obs/model value (normalized with the highest value for each mode "fine" and "coarse" at each location). The blue circles represent the scale for the results, with examples for sizes representing 10,50 and $100 \%$.

\section{Conclusions}

Studying aerosol composition and size distribution is a scientific challenge that can lead to a better understanding of the aerosol life cycle and improve our understanding of the aerosol impact on health and climate. This is also necessary if we want to split the relative contribution of anthropogenic and biogenic parts in the aerosol to be able to adapt and have more efficient rules of $\mathrm{AQ}$ legislation.

This modeling study presents the analysis of a simulation performed with the WRF and CHIMERE models, over a large region including Africa, Mediterranean region and western Europe. The simulation was performed for the 2 months of June and July 2013 and includes all aerosol sources and chemical types. In order to estimate the model accuracy, the AOD and AE are compared to the AERONET photometers measurements. For AOD, it is shown that the correlation varies a lot from south (Africa, with high correlations) to north (Europe, with low correlations) with a mean averaged value of 0.3 . The spatial correlation is better, 0.9, and showed that if the events are not temporally well modeled, the large spatial structures of dense plumes are well estimated by the model. This is confirmed by the good scores with the AE, showing that the origin of the air masses and thus the relative abundance of fine/coarse aerosol is correctly retrieved by the model (spatial correlation of 0.96). The $\mathrm{PM}_{2.5}$ and $\mathrm{PM}_{10}$ surface concentrations are compared to the EMEP network measurements. A mean averaged cor-
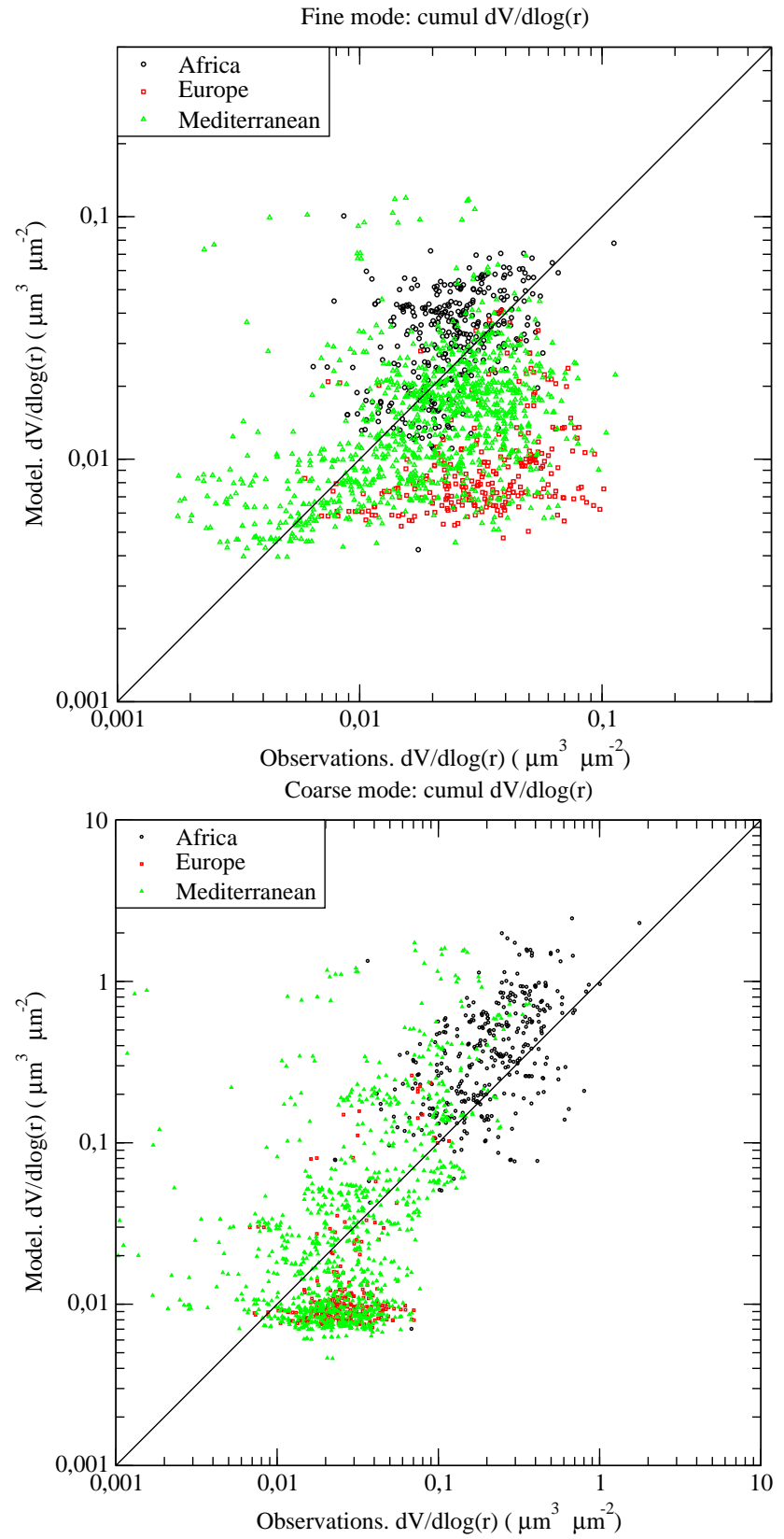

Figure 12. Scatter plots for comparisons between the observations and the model for the aerosol size distribution. Each plot corresponds to the sum of the concentrations of aerosol for the "fine" mode $(r<0.5 \mu \mathrm{m})$ and the "coarse" mode $(r>0.5 \mu \mathrm{m})$. Each point corresponds to an hour during the whole simulation and a modeled concentration corresponding to an AERONET site. The sites are split in three families: Africa (black symbols), Europe (red symbols) and Mediterranean region (green symbols), following the classification explained in Table 2.

relation of 0.42 and 0.44 is found, with negative biases of -0.49 and $-1.10 \mu \mathrm{g} \mathrm{m}^{-3}$.

To go further in the analysis, several additional measurements are added to this observations vs. model comparison. 
First, this study takes advantages of the availability of surface measurements of inorganic chemical species such as nitrate, sulfate and ammonium. The equivalent species are modeled with CHIMERE and it is shown that the mean averaged correlation is $0.25,0.37$ and 0.17 , for these three species, respectively. The spatial correlation is different and is 0.25 , 0.5 and 0.87 , respectively. This shows that if some bias remain in the modeling of these species, the spatial localization of sulfate and ammonium is well captured by the model. The modeling of the nitrate is the weak point for these inorganic species, certainly due to missing sources and processes such as the calculation of coarse nitrate. Second, we take advantage of the AERONET inversion products to estimate the model capability to retrieve the aerosol size distribution over this large region. It is shown that the two main observed modes are well estimated: in Africa, the model is able to correctly estimate the observed radius of the AERONET distribution, while the largest variability is diagnosed in the Mediterranean region and Europe. In mass, the aerosol fine mode is overestimated in Africa but underestimated in Europe. As the Mediterranean region has aerosol that is a mix between African sources (mainly mineral dust), local sea salt and European sources, the modeled mass in the fine mode exhibits a large variability compared to the measurements. Results in mass are better for the coarse mode, but always with a slight model overestimation in Africa and a model underestimation in Europe.

This study shows that the CTM CHIMERE reproduces the main part of the observed aerosol composition variability over several regions as Africa, the Mediterranean region and Europe. By splitting the analysis in terms of chemical composition, it is shown that the scores obtained for $\mathrm{PM}_{2.5}$ and $\mathrm{PM}_{10}$ are not due to model errors compensation, the order of magnitude and time variability of inorganic species being correctly reproduced. The next step will be to reduce the uncertainties on (i) the mineral dust emissions in Africa, representing a large part of the model error after long-range transport from Africa to Europe and (ii) the sources and chemistry of nitrate.

Acknowledgements. INERIS is funded by the French Ministry of Ecology, Sustainable Development and Energy. The EBAS database has largely been funded by the CLRTAP-EMEP programme, AMAP and NILU internal resources. Specific developments have been possible due to projects like EUSAAR (EBAS web interface), EBAS-Online (upgrading of database platform) and HTAP (import and export routines to build a secondary repository in support of www.htap.org. A large number of specific projects have supported development of data and metadata reporting schemes in dialog with data providers (CREATE, ACTRIS and others).

Edited by: J.-L. Attie

Reviewed by: two anonymous referees

\section{References}

Alfaro, S. C. and Gomes, L.: Modeling mineral aerosol production by wind erosion: Emission intensities and aerosol size distribution in source areas, J. Geophys. Res., 106, 18075-18084, 2001.

Aymoz, G., Jaffrezo, J.-L., Jacob, V., Colomb, A., and George, Ch.: Evolution of organic and inorganic components of aerosol during a Saharan dust episode observed in the French Alps, Atmos. Chem. Phys., 4, 2499-2512, doi:10.5194/acp-4-2499-2004, 2004.

Berg, L. K., Fast, J. D., Barnard, J. C., Burton, S. P., Cairns, B., Chand, D., Comstock, J. M., Dunagan, S., Ferrare, R. A., Flynn, C. J., Hair, J. W., Hostetler, C. A., Hubbe, J., Jefferson, A., Johnson, R., Kassianov, E. I., Kluzek, C. D., Kollias, P., Lamer, K., Lantz, K., Mei, F., Miller, M. A., Michalsky, J., Ortega, I., Pekour, M., Rogers, R. R., Russell, P. B., Redemann, J., Sedlacek, A. J., Segal-Rosenheimer, M., Schmid, B., Shilling, J. E., Shinozuka, Y., Springston, S. R., Tomlinson, J. M., Tyrrell, M., Wilson, J. M., Volkamer, R., Zelenyuk, A., and Berkowitz, C. M.: The Two-Column Aerosol Project: Phase I: Overview and impact of elevated aerosol layers on aerosol optical depth, J. Geophys. Res.-Atmos., 121, 336-361, doi:10.1002/2015JD023848, 2015.

Bergström, R., Denier van der Gon, H. A. C., Prévôt, A. S. H., Yttri, K. E., and Simpson, D.: Modelling of organic aerosols over Europe (2002-2007) using a volatility basis set (VBS) framework: application of different assumptions regarding the formation of secondary organic aerosol, Atmos. Chem. Phys., 12, 8499-8527, doi:10.5194/acp-12-8499-2012, 2012.

Bessagnet, B., Hodzic, A., Vautard, R., Beekmann, M., Cheinet, S., Honoré, C., Liousse, C., and Rouil, L.: Aerosol modeling with CHIMERE: preliminary evaluation at the continental scale, Atmos. Environ., 38, 2803-2817, 2004.

Bessagnet, B., Pirovano, G., Mircea, M., Cuvelier, C., Aulinger, A., Calori, G., Ciarelli, G., Manders, A., Stern, R., Tsyro, S., García Vivanco, M., Thunis, P., Pay, M.-T., Colette, A., Couvidat, F., Meleux, F., Rouïl, L., Ung, A., Aksoyoglu, S., Baldasano, J. M., Bieser, J., Briganti, G., Cappelletti, A., D'Isodoro, M., Finardi, S., Kranenburg, R., Silibello, C., Carnevale, C., Aas, W., Dupont, J.-C., Fagerli, H., Gonzalez, L., Menut, L., Prévôt, A. S. H., Roberts, P., and White, L.: Presentation of the EURODELTA III inter-comparison exercise - Evaluation of the chemistry transport models performance on criteria pollutants and joint analysis with meteorology, Atmos. Chem. Phys. Discuss., doi:10.5194/acp2015-736, in review, 2016.

Bian, H. and Prather, M.: Fast-J2: accurate simulation of stratospheric photolysis in global chemical models, J. Atmos. Chem. 41, 281-296, 2002.

Chen, F. and Dudhia, J.: Coupling an advanced land surfacehydrology model with the Penn State-NCAR MM5 modeling system. Part I: Model implementation and sensitivity, Mon. Weather Rev., 129, 569-585, 2001.

di Sarra, A., Pace, G., Meloni, D., De Silvestri, L., Piacentino, S., and Monteleone, F.: Surface shortwave radiative forcing of different aerosol types in the central Mediterranean, Geophys. Res. Lett., 35, L02714, doi:10.1029/2007GL032395, 2008.

Dubovik, O. and King, M. D.: A flexible inversion algorithm for retrieval of aerosol optical properties from Sun and sky radiance measurements, J. Geophys. Res.-Atmos., 105, 20673-20696, doi:10.1029/2000JD900282, 2000. 
Escudero, M., Querol, X., Pey, J., Alastuey, A., Perez, N., Ferreira, F., Alonso, S., Rodriguez, S., and Cuevas, E.: A methodology for the quantification of the net African dust load in air quality monitoring networks, Atmos. Environ., 41, 5516-5524, 2007.

European Union: Ambient air quality and cleaner air for Europe, Directive 2008/50/EC of the European Parliament and of the Council of 21 May 2008 OJ L 152, 1-44, available at: http://eur-lex. europa.eu/legal-content/EN/TXT/?uri=celex:32008L0050 (last access: 30 March 2016), 2008.

Fountoukis, C., Megaritis, A. G., Skyllakou, K., Charalampidis, P. E., Pilinis, C., Denier van der Gon, H. A. C., Crippa, M., Canonaco, F., Mohr, C., Prévôt, A. S. H., Allan, J. D., Poulain, L., Petäjä, T., Tiitta, P., Carbone, S., Kiendler-Scharr, A., Nemitz, E., O'Dowd, C., Swietlicki, E., and Pandis, S. N.: Organic aerosol concentration and composition over Europe: insights from comparison of regional model predictions with aerosol mass spectrometer factor analysis, Atmos. Chem. Phys., 14, 9061-9076, doi:10.5194/acp-14-9061-2014, 2014.

Ginoux, P., Chin, M., Tegen, I., Prospero, J. M., Holben, B., Dubovik, O., and Lin, S. J.: Sources and distributions of dust aerosols simulated with the GOCART model, J. Geophys. Res., 106, 20255-20273, 2001.

Grell, G. and Dévényi, D.: A generalized approach to parameterizing convection combining ensemble and data assimilation techniques, Geophys. Res. Lett., 29, 38-1-38-4, doi:10.1029/2002GL015311, 2002.

Guenther, A., Karl, T., Harley, P., Wiedinmyer, C., Palmer, P. I., and Geron, C.: Estimates of global terrestrial isoprene emissions using MEGAN (Model of Emissions of Gases and Aerosols from Nature), Atmos. Chem. Phys., 6, 3181-3210, doi:10.5194/acp-63181-2006, 2006.

Guerreiro, C., de Leuw, F., and Foltescu, V.: Air quality in Europe, European Environment Agency, report, 9, 112, 2013.

Helmert, J., Hinold, B., Tegen, I., Hellmuth, O., and Wendish, M.: On the direct and semidirect effects of Saharan dust over Europe: A modeling study, J. Geophys. Res., 112, D13208, doi:10.1029/2006JD007444, 2007.

Hodzic, A., Bessagnet, B., and Vautard, R.: A model evaluation of coarse-mode nitrate heterogeneous formation on dust particles, Atmos. Environ., 40, 4158-4171, 2006.

Holben, B., Tanre, D., Smirnov, A., Eck, T. F., Slutsker, I., Abuhassan, N., Newcomb, W. W., Schafer, J., Chatenet, B., Lavenu, F., Kaufman, Y. J., Vande Castle, J., Setzer, A., Markham, B., Clark, D., Frouin, R., Halthore, R., Karnieli, A., O’Neill, N. T., Pietras, C., Pinker, R. T., Voss, K., and Zibordi, G.: An emerging ground-based aerosol climatology: Aerosol Optical Depth from AERONET, J. Geophys. Res., 106, 12067-12097, 2001.

Hong, S. Y., Dudhia, J., and Chen, S.: A revised approach to ice microphysical processes for the bulk parameterization of clouds and precipitation, Mon. Weather Rev., 132, 103-120, 2004.

Hong, S. Y., Noh, Y., and Dudhia, J.: A new vertical diffusion package with an explicit treatment of entrainment processes, Mon. Weather Rev., 134, 2318-2341, doi:10.1175/MWR3199.1, 2006.

Huneeus, N., Schulz, M., Balkanski, Y., Griesfeller, J., Prospero, J., Kinne, S., Bauer, S., Boucher, O., Chin, M., Dentener, F., Diehl, T., Easter, R., Fillmore, D., Ghan, S., Ginoux, P., Grini, A., Horowitz, L., Koch, D., Krol, M. C., Landing, W., Liu, X., Mahowald, N., Miller, R., Morcrette, J.-J., Myhre, G., Penner, J., Perlwitz, J., Stier, P., Takemura, T., and Zender, C. S.: Global dust model intercomparison in AeroCom phase I, Atmos. Chem. Phys., 11, 7781-7816, doi:10.5194/acp-11-7781-2011, 2011.

Janssens-Maenhout, G., Dentener, F., Van Aardenne, J., Monni, S., Pagliari, V., Orlandini, L., Klimont, Z., Kurokawa, J.-I., H., A., Ohara, T., Wankmueller, R., Battye, B., Grano, D., Zuber, A., and Keating, T.: EDGAR-HTAP: a harmonized gridded air pollution emission dataset based on national inventories, Publications Office of the European Union, JRC68434, doi:10.2788/14102, 2012.

Kostenidou, E., Florou, K., Kaltsonoudis, C., Tsiflikiotou, M., Vratolis, S., Eleftheriadis, K., and Pandis, S. N.: Sources and chemical characterization of organic aerosol during the summer in the eastern Mediterranean, Atmos. Chem. Phys., 15, 11355-11371, doi:10.5194/acp-15-11355-2015, 2015.

Kulmala, M., Asmi, A., Lappalainen, H. K., Baltensperger, U., Brenguier, J.-L., Facchini, M. C., Hansson, H.-C., Hov, Ø., O’Dowd, C. D., Pöschl, U., Wiedensohler, A., Boers, R., Boucher, O., de Leeuw, G., Denier van der Gon, H. A. C., Feichter, J., Krejci, R., Laj, P., Lihavainen, H., Lohmann, U., McFiggans, G., Mentel, T., Pilinis, C., Riipinen, I., Schulz, M., Stohl, A., Swietlicki, E., Vignati, E., Alves, C., Amann, M., Ammann, M., Arabas, S., Artaxo, P., Baars, H., Beddows, D. C. S., Bergström, R., Beukes, J. P., Bilde, M., Burkhart, J. F., Canonaco, F., Clegg, S. L., Coe, H., Crumeyrolle, S., D’Anna, B., Decesari, S., Gilardoni, S., Fischer, M., Fjaeraa, A. M., Fountoukis, C., George, C., Gomes, L., Halloran, P., Hamburger, T., Harrison, R. M., Herrmann, H., Hoffmann, T., Hoose, C., Hu, M., Hyvärinen, A., Hõrrak, U., Iinuma, Y., Iversen, T., Josipovic, M., Kanakidou, M., Kiendler-Scharr, A., Kirkevåg, A., Kiss, G., Klimont, Z., Kolmonen, P., Komppula, M., Kristjánsson, J.-E., Laakso, L., Laaksonen, A., Labonnote, L., Lanz, V. A., Lehtinen, K. E. J., Rizzo, L. V., Makkonen, R., Manninen, H. E., McMeeking, G., Merikanto, J., Minikin, A., Mirme, S., Morgan, W. T., Nemitz, E., O’Donnell, D., Panwar, T. S., Pawlowska, H., Petzold, A., Pienaar, J. J., Pio, C., Plass-Duelmer, C., Prévôt, A. S. H., Pryor, S., Reddington, C. L., Roberts, G., Rosenfeld, D., Schwarz, J., Seland, Ø., Sellegri, K., Shen, X. J., Shiraiwa, M., Siebert, H., Sierau, B., Simpson, D., Sun, J. Y., Topping, D., Tunved, P., Vaattovaara, P., Vakkari, V., Veefkind, J. P., Visschedijk, A., Vuollekoski, H., Vuolo, R., Wehner, B., Wildt, J., Woodward, S., Worsnop, D. R., van Zadelhoff, G.-J., Zardini, A. A., Zhang, K., van Zyl, P. G., Kerminen, V.-M., S Carslaw, K., and Pandis, S. N.: General overview: European Integrated project on Aerosol Cloud Climate and Air Quality interactions (EUCAARI) - integrating aerosol research from nano to global scales, Atmos. Chem. Phys., 11, 13061-13143, doi:10.5194/acp11-13061-2011, 2011.

Laj, P., Klausen, J., Bilde, M., Plas-Duelmer, C., Pappalardo, G., Clerbaux, C., Baltensperger, U., Hjorth, J., Simpson, D., Reimann, S., Coheur, P.-F., Richter, A., Mazière, M. D., Rudich, Y., McFiggans, G., Torseth, K., Wiedensohler, A., Morin, S., Schulz, M., Allan, J., Attié, J.-L., Barnes, I., Birmili, W., Cammas, J., Dommen, J., Dorn, H.-P., Fowler, D., Fuzzi, S., Glasius, M., Granier, C., Hermann, M., Isaksen, I., Kinne, S., Koren, I., Madonna, F., Maione, M., Massling, A., Moehler, O., Mona, L., Monks, P., Muller, D., Muller, T., Orphal, J., Peuch, V.-H., Stratmann, F., Tanré, D., Tyndall, G., Riziq, A. A., Roozendael, M. V., Villani, P., Wehner, B., Wex, H., and Zardini, A.: Mea- 
suring atmospheric composition change, Atmos. Environ., 43, 5351-5414, doi:10.1016/j.atmosenv.2009.08.020, 2009.

Mailler, S., Menut, L., di Sarra, A. G., Becagli, S., Di Iorio, T., Bessagnet, B., Briant, R., Formenti, P., Doussin, J.-F., Gómez-Amo, J. L., Mallet, M., Rea, G., Siour, G., Sferlazzo, D. M., Traversi, R., Udisti, R., and Turquety, S.: On the radiative impact of aerosols on photolysis rates: comparison of simulations and observations in the Lampedusa island during the ChArMEx/ADRIMED campaign, Atmos. Chem. Phys., 16, 1219-1244, doi:10.5194/acp-16-1219-2016, 2016 a.

Mailler, S., Menut, L., Khvorostyanov, D., Valari, M., Couvidat, F., Siour, G., Turquety, S., Briant, R., Tuccella, P., Bessagnet, B., Colette, A., Létinois, L., and Meleux, F.: CHIMERE2016: From urban to hemispheric chemistry-transport modeling, Geosci. Model Dev. Discuss., doi:10.5194/gmd-2016-196, in review, 2016b.

Mallet, M., Dulac, F., Formenti, P., Nabat, P., Sciare, J., Roberts, G., Pelon, J., Ancellet, G., Tanré, D., Parol, F., Denjean, C., Brogniez, G., di Sarra, A., Alados-Arboledas, L., Arndt, J., Auriol, F., Blarel, L., Bourrianne, T., Chazette, P., Chevaillier, S., Claeys, M., D’Anna, B., Derimian, Y., Desboeufs, K., Di Iorio, T., Doussin, J.-F., Durand, P., Féron, A., Freney, E., Gaimoz, C., Goloub, P., Gómez-Amo, J. L., Granados-Muñoz, M. J., Grand, N., Hamonou, E., Jankowiak, I., Jeannot, M., Léon, J.-F., Maillé, M., Mailler, S., Meloni, D., Menut, L., Momboisse, G., Nicolas, J., Podvin, T., Pont, V., Rea, G., Renard, J.-B., Roblou, L., Schepanski, K., Schwarzenboeck, A., Sellegri, K., Sicard, M., Solmon, F., Somot, S., Torres, B., Totems, J., Triquet, S., Verdier, N., Verwaerde, C., Waquet, F., Wenger, J., and Zapf, P.: Overview of the Chemistry-Aerosol Mediterranean Experiment/Aerosol Direct Radiative Forcing on the Mediterranean Climate (ChArMEx/ADRIMED) summer 2013 campaign, Atmos. Chem. Phys., 16, 455-504, doi:10.5194/acp-16-455-2016, 2016.

Martinelli, N., Olivieri, O., and Girelli, D.: Air particulate matter and cardiovascular disease: A narrative review, European Journal of Internal Medicine, 24, 295-302, doi:10.1016/j.ejim.2013.04.001, 2013.

Menut, L., Goussebaile, A., Bessagnet, B., Khvorostiyanov, D., and Ung, A.: Impact of realistic hourly emissions profiles on modelled air pollutants concentrations, Atmos. Environ., 49, 233244, doi:10.1016/j.atmosenv.2011.11.057, 2012.

Menut, L., Bessagnet, B., Khvorostyanov, D., Beekmann, M., Blond, N., Colette, A., Coll, I., Curci, G., Foret, G., Hodzic, A., Mailler, S., Meleux, F., Monge, J.-L., Pison, I., Siour, G., Turquety, S., Valari, M., Vautard, R., and Vivanco, M. G.: CHIMERE 2013: a model for regional atmospheric composition modelling, Geosci. Model Dev., 6, 981-1028, doi:10.5194/gmd6-981-2013, 2013a.

Menut, L., Perez Garcia-Pando, C., Haustein, K., Bessagnet, B., Prigent, C., and Alfaro, S.: Relative impact of roughness and soil texture on mineral dust emission fluxes modeling, J. Geophys. Res., 118, 6505-6520, doi:10.1002/jgrd.50313, 2013b.

Menut, L., Mailler, S., Siour, G., Bessagnet, B., Turquety, S., Rea, G., Briant, R., Mallet, M., Sciare, J., Formenti, P., and Meleux, F.: Ozone and aerosol tropospheric concentrations variability analyzed using the ADRIMED measurements and the WRF and CHIMERE models, Atmos. Chem. Phys., 15, 6159-6182, doi:10.5194/acp-15-6159-2015, 2015.a.
Menut, L., Rea, G., Mailler, S., Khvorostyanov, D., and Turquety, S.: Aerosol forecast over the Mediterranean area during July 2013 (ADRIMED/CHARMEX), Atmos. Chem. Phys., 15, 78977911, doi:10.5194/acp-15-7897-2015, 2015b.

Mlawer, E., Taubman, S., Brown, P., Iacono, M., and Clough, S.: Radiative transfer for inhomogeneous atmospheres: RRTM a validated correlated-k model for the longwave, J. Geophys. Res., 102, 16663-16682, 1997.

Monahan, E. C.: In The Role of Air-Sea Exchange in Geochemical Cycling, chap. The ocean as a source of atmospheric particles, 129-163, Kluwer Academic Publishers, Dordrecht, Holland, 1986.

Nenes, A., Pilinis, C., and Pandis, S.: ISORROPIA: A new thermodynamic model for inorganic multicomponent atmospheric aerosols, Aquat. Geochem., 4, 123-152, 1998.

Péré, J., Mallet, M., Pont, V., and Bessagnet, B.: Evaluation of an aerosol optical scheme in the chemistry-transport model CHIMERE, Atmos. Environ., 44, 3688-3699, 2010.

Putaud, J.-P., Raes, F., Van Dingenen, R., Bruggemann, E., Facchini, M.-C., Decesari, S., Fuzzi, S., Gehrig, R., Huglin, C., Laj, P., Lorbeer, G., Maenhaut, W., Mihalopoulos, N., Muller, K., Querol, X., Rodriguez, S., Schneider, J., Spindler, G., Ten Brink, H., Torseth, K., and Wiedensohler, A.: A European aerosol phenomenology - 2: chemical characteristics of particulate matter at kerbside, urban, rural and background sites in Europe, Atmos. Environ., 38, 2579-2595, 2004

Querol, X., Alastuey, A., Ruiz, C.-R., Artinano, B., Hansson, H. C., Harrison, R. M., Buringh, E., ten Brink, H. M., Lutz, M., Bruckmann, P., Straehl, P., and Schneider, J.: Speciation and origin of PM10 and PM2.5 in selected European cities, Atmos. Environ., 38, 6547-6555, 2004.

Rea, G., Turquety, S., Menut, L., Briant, R., Mailler, S., and Siour, G.: Source contributions to 2012 summertime aerosols in the Euro-Mediterranean region, Atmos. Chem. Phys., 15, 8013 8036, doi:10.5194/acp-15-8013-2015, 2015.

Rouil, L. and Bessagnet, B.: How to start with PM modelling for air quality assessment and planning relevant to the Air Quality Directive, ETC/ACM Technical Paper, 2013/11, 2014.

Schutgens, N. A. J. and Stier, P.: A pathway analysis of global aerosol processes, Atmos. Chem. Phys., 14, 11657-11686, doi:10.5194/acp-14-11657-2014, 2014.

Skamarock, W., Klemp, J., Dudhia, J., Gill, D., Barker, D., Wang, W., and Powers, J.: A Description of the Advanced Research WRF Version 2, NCAR Technical Note, NCAR/TN-468+STR, 2007.

Solazzo, E., Bianconi, R., Vautard, R., Appel, K. W., Moran, M. D., Hogrefe, C., Bessagnet, B., Brandt, J., Christensen, J. H., Chemel, C., Coll, I., van der Gon, H. D., Ferreira, J., Forkel, R., Francis, X. V., Grell, G., Grossi, P., Hansen, A. B., Jericevic, A., Kraljevic, L., Miranda, A. I., Nopmongcol, U., Pirovano, G., Prank, M., Riccio, A., Sartelet, K. N., Schaap, M., Silver, J. D., Sokhi, R. S., Vira, J., Werhahn, J., Wolke, R., Yarwood, G., Zhang, J., Rao, S., and Galmarini, S.: Model evaluation and ensemble modelling of surface-level ozone in Europe and North America in the context of AQMEII, Atmos. Environ., 53, 60-74, doi:10.1016/j.atmosenv.2012.01.003, 2012.

Stocker, T., Qin, D., Plattner, G.-K., Tignor, M., Allen, S., Boschung, J., Nauels, A., Xia, Y., Bex, V., and Midgley, P.: Climate Change 2013: The Physical Science Basis. Contribution of 
Working Group I to the Fifth Assessment, Report of the Intergovernmental Panel on Climate Change, IPCC, 1535, 2013.

Szopa, S., Foret, G., Menut, L., and Cozic, A.: Impact of large scale circulation on European summer surface ozone: consequences for modeling, Atmos. Environ., 43, 1189-1195, doi:10.1016/j.atmosenv.2008.10.039, 2009.

Tegen, I., Hollrig, P., Chin, M., Fung, I., Jacob, D., and Penner, J.: Contribution of Different Aerosol Species to the Global Aerosol Extinction Optical Thickness: Estimates From Model Results, J. Geophys. Res., 102, 23895-23915, 1997.

Viana, M., Kuhlbusch, T., Querol, X., Alastuey, A., Harrison, R., Hopke, P., Winiwarter, W., Vallius, A., Szidat, S., Prevot, A., Hueglin, C., Bloemen, H., Wahlin, P., Vecchi, R., Miranda, A., Kasper-Giebl, A., Maenhaut, W., and Hitzenbergerq, R.: Source apportionment of particulate matter in Europe: A review of methods and results, J. Aerosol Sci., 39, 827-849, 2008.
Vogel, B., Vogel, H., Bäumer, D., Bangert, M., Lundgren, K., Rinke, R., and Stanelle, T.: The comprehensive model system COSMOART - Radiative impact of aerosol on the state of the atmosphere on the regional scale, Atmos. Chem. Phys., 9, 8661-8680, doi:10.5194/acp-9-8661-2009, 2009.

Von Storch, H., Langenberg, H., and Feser, F.: A spectral nudging technique for dynamical downscaling purposes, Mon. Weather Rev., 128, 3664-3673, 2000.

Wild, O., Zhu, X., and Prather, M. J.: Fast-J: Accurate Simulation of In- and Below-Cloud Photolysis in Tropospheric Chemical Models, J. Atmos. Chem., 37, 245-282, 2000. 